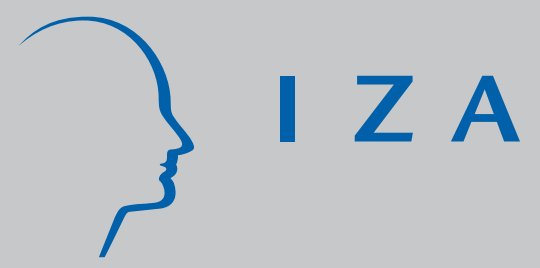

IZA DP No. 38

J ob Satisfaction within the Scottish Academic Profession

Melanie E. Ward

Peter J. Sloane

April 1999 


\title{
Job Satisfaction within the Scottish Academic Profession
}

\author{
Melanie E. Ward \\ Peter J. Sloane
}

Discussion Paper No. 38
April 1999

IZA

P.O. Box 7240

D-53072 Bonn

Germany

Tel.: +49-228-3894-0

Fax: +49-228-3894-210

Email: iza@iza.org

This Discussion Paper is issued within the framework of IZA's research area General Labor Economics. Any opinions expressed here are those of the author(s) and not those of the institute. Research disseminated by IZA may include views on policy, but the institute itself takes no institutional policy positions.

The Institute for the Study of Labor (IZA) in Bonn is a local and virtual international research center and a place of communication between science, politics and business. IZA is an independent, nonprofit limited liability company (Gesellschaft mit beschränkter Haftung) supported by the Deutsche Post AG. The center is associated with the University of Bonn and offers a stimulating research environment through its research networks, research support, and visitors and doctoral programs. IZA engages in (i) original and internationally competitive research in all fields of labor economics, (ii) development of policy concepts, and (iii) dissemination of research results and concepts to the interested public. The current research program deals with (1) mobility and flexibility of labor markets, (2) internationalization of labor markets and European integration, (3) the welfare state and labor markets, (4) labor markets in transition, (5) the future of work, and (6) general labor economics.

IZA Discussion Papers often represent preliminary work and are circulated to encourage discussion. Citation of such a paper should account for its provisional character. 
IZA Discussion Paper No. 38

April 1999

\section{ABSTRACT}

\section{Job Satisfaction within the Scottish Academic Profession}

This paper considers job satisfaction in the academic labour market drawing upon a particularly detailed data set of 900 academics from five traditional Scottish Universities. Recent studies have revealed that in the labour force as a whole women generally express themselves as more satisfied with their jobs than men. Our results show that reports of overall job satisfaction do not vary widely by gender. This result is explained through the nature of our dataset, limited as it is to a highly educated workforce, in which female workers are likely to have job expectations comparable to their male counterparts. Ordered probit analysis is used to analyse the determinants of an academic's overall satisfaction at work as well as satisfaction with promotion prospects, job security and salary. Comparison salary is found to be an important influence on academics' overall job satisfaction although evidence suggests that academics place a lower emphasis on pecuniary relative to non pecuniary aspects of work than other sectors of the workforce.

JEL Classification: J44

Keywords: Job satisfaction, academic labour market, gender differences.

Melanie E. Ward

IZA

P.O. Box 7240

D-53072 Bonn

Germany

Tel: +492283894306

Fax: +492283894210

e-mail: Ward@iza.org

\footnotetext{
"The authors are grateful to participants at the European Association of Labour Economists Annual Conference, University of Aarhus, and the Society of Population Economists Annual Conference, University of Essex and two anonymous referees for helpful comments and for funding from the Scottish Economic Society.
} 


\section{INTRODUCTION}

Previous research into job satisfaction in the labour market has shown that women consistently express themselves as more satisfied with their jobs than men ${ }^{1}$. This is surprising, given that numerous studies across occupations and countries have found substantial and significant malefemale earnings differentials ${ }^{2}$ and there is evidence of discrimination against women in areas of the labour market such as hiring/firing ${ }^{3}$ and promotion ${ }^{4}$. Here we focus on job satisfaction in a single occupation in which both men and women are well represented though their distribution differs across disciplines, and examine whether or not job satisfaction follows a similar pattern to that in the generality of occupations.

In analysing job satisfaction care needs to be taken over individuals' differing interpretation of questions and measurement scales, as a result of the differing ways in which language is processed, together with any personality differences which may also affect the way in which individuals respond to questions. It has been shown, however, that such responses concerning job satisfaction can be strong predictors of individuals' behaviour. For example, in cross section studies job satisfaction has predicted quits, absenteeism and worker productivity ${ }^{5}$. Thus, although it may be true that one worker's reported level of job satisfaction as 'very satisfied' may not be identical to the next worker's, it can be argued that he or she will be less likely to quit or have time away from work and be more productive than a worker with lower reported job satisfaction. Strong correlations between job satisfaction and other observable events and actions concerning the labour force have also been found ${ }^{6}$. Together, these correlations provide the main justification for studying subjective assessments of job satisfaction ${ }^{7}$.

\footnotetext{
${ }^{1}$ See for example, Clark (1996, 1997), Sloane and Williams (1996a, 1996b).

${ }^{2}$ See for example, Greenhalgh (1980), Dolton and Makepeace (1985), Zabalza and Arrufat (1985), Joshi and Newell (1987), Miller (1987) and Wright and Ermisch (1991).

${ }^{3}$ See for example, Riach and Rich (1987).

${ }^{4}$ See for example Lazear and Rosen (1990) and Weiler (1990).

${ }^{5}$ Akerlof, Rose and Yellen (1988), Freeman (1978), Hamermesh (1977), and McEvoy and Cascio (1985) find that job satisfaction predicts future quits. Clegg (1983) and Mangione and Quinn (1975) find job satisfaction to be negatively correlated with absenteeism and worker productivity.

${ }^{6}$ See Clark and Oswald (1996) for a discussion of these.

${ }^{7}$ The homogeneity of the sample under consideration (highly educated workers within the same occupation) also offers reasonable assurance that any unmeasured characteristic influences on reported of job satisfaction
} 
The economic literature on job satisfaction to date can be divided into studies considering the workforce as a whole ${ }^{8}$, those which focus on race or gender ${ }^{9}$, those which analyse the effect of trade union membership ${ }^{10}$ and those considering establishment size ${ }^{11}$. This paper considers gender differences in the academic labour market, which possesses some unique features. Academics are a relatively homogeneous group in terms of their motivation and investment in human capital. They have generally undertaken periods of extended study relative to the general labour force at an opportunity cost of perhaps considerable foregone earnings. Flexibility in working hours - both in the absolute number worked per week and their distribution - provides a stark difference between a conventional working population and an academic one. A British academic has no hours stipulated in his or her contract, or even a rigidly defined place of work. An academic may therefore choose, around the constraint of set teaching hours, where and when he or she wants to work and can work with relative freedom. One might therefore expect women to have stronger long term work commitments than women in other labour markets - partly due to the large investments in human capital, and partly to the fact that flexibility of academic career is more likely to allow a woman to combine a career with domestic and family responsibilities. There are, therefore, relatively high nonpecuniary advantages of academic employment which may influence job satisfaction by gender.

In contrast there is a relatively rigid system of pay determination which has produced declining relative incomes for academics. Advancement is by number of years of experience, with a pay increment at the end of each year in accordance with a nationally agreed scale. Hiring and promotion is centrally rather than department based. Not only is pay low but there are also few fringe benefits with a relative absence of benefits such as company cars, subsidised meals and profit sharing schemes. As university staff are generally regarded as low-paid ${ }^{12}$ given their qualifications ${ }^{13}$ this provides a useful laboratory for testing whether non-pecuniary advantages of academic employment can compensate for unfavourable pay. The available data allow us to analyse not only the effect of absolute and objective pay comparisons on reported job

are unlikely to vary systematically with the explanatory variables. Normal assumptions about the error distribution therefore hold.

${ }^{8}$ For example Hamermesh (1977), Clark (1996), Clark and Oswald (1996).

${ }^{9}$ For example Bartel (1981), Clark (1995), Sloane and Williams (1996b)

${ }^{10}$ For example Borjas (1979) and Miller (1990)

${ }^{11}$ Idson (1990)

${ }^{12}$ National Committee of Inquiry into Higher Education (1997)

${ }^{13}$ We have also found evidence to suggest that over half of academics themselves feel underpaid. 
satisfaction, but also subjective pay comparisons based on perceptions of deserved levels of pay.

This paper begins with consideration of the methodology used in previous labour market studies of gender differences in job satisfaction. Its application to the case of the Scottish academic profession provides the first detailed information concerning the job satisfaction of academics. Ordered probit analysis is used to analyse the determinants of an academic's overall satisfaction at work as well as job satisfaction with promotion prospects, job security and salary. Finally, the main conclusions of this paper are summarised.

\section{Methodology}

A number of potential explanations have been put forward in studies of the workforce as a whole to try and explain female workers' apparently higher levels of job satisfaction. Thus, it has been suggested that women may have different attitudes or 'tastes' concerning what factors are important in their job relative to men and this may explain the gender satisfaction gap. Clark (1997), for example, finds that female workers within the British Household Panel Study mention good managers, the actual work they do and hours of work more frequently than men as being important to them in their job. In contrast, men were found to rank promotion prospects, pay and job security more highly. Sloane and Williams (1996a) remark that perhaps the persistence of occupational segregation by gender is a result of differing tastes for work between the sexes and find using Social Change and Economic Life data that men may seek jobs in which pecuniary factors such as overtime hours are emphasised and women those in which flexible hours of work and other non-pecuniary aspects predominate.

It is standard practice in economics to represent utility functions as depending only on absolute levels of variables. However, a second reason suggested to explain the gender job satisfaction gap is that workers have some idea of relative or comparison income which enters their utility function. Therefore individual job satisfaction is not only affected by their own absolute income 
level, but also by their income relative to some expected level or comparison group ${ }^{14}$. Following Clark and Oswald (1996) and Clark (1997), we can re-write a standard utility function, where utility $(u)$, depends on levels of absolute income $(y)$, hours worked $(h)$, a vector of personal characteristics $(z)$ and a vector of job characteristics $(j)$ to include an additional variable $\left(y^{*}\right)$ which gives some idea of an individual's reference income.

$$
u=u\left(y, y^{*}, h, z, j\right)
$$

Utility therefore increases with income and decreases in hours worked as usual, but now also decreases with a rise in $y^{*}$, representing an individual's income expectations, or a reference group's earnings. The new utility function implies that workers compare their present income level with some expected level, or the income of others in order to evaluate whether or not they are satisfied. From this analysis it can be seen that lower levels of $y^{*}$ for women than men may explain female workers higher levels of job satisfaction. In the case of academics we are interested to discover whether relatively low pay increases the significance of pay comparisons or whether a preference for non-pecuniary elements of work reduces their significance.

But why might female workers have a lower $y^{*}$ than men? Age, occupation, education and labour market participation have all been put forward as possible influences lowering female worker's expectations ${ }^{15}$. The simplified arguments are as follows: Firstly, older women may expect less from their jobs than younger women because of the more restricted role for women in the labour markets that they observed and grew up in ${ }^{16}$. Education and experience in a good job might provide mechanisms whereby levels of expectation could be revised upwards. Therefore, the less educated female workers and women in the lower ranking occupational

\footnotetext{
${ }^{14}$ This idea was first proposed in the job satisfaction literature by Hamermesh (1977), although including some idea of reference income in the utility function has been proposed by a number of economists, some of which are listed by Clark and Oswald (1996).

${ }^{15}$ See for example, Clark (1997).

${ }^{16}$ In contrast, male workers, old and young alike, will have similarly high job expectations due to the relative stability of male opportunities in the workplace.
} 
categories might harbour relatively lower expectations ${ }^{17}$. Finally, the alternative to a paid job may alter female worker's expectations. Women, happy to be in the labour market, therefore expect less from their workplace ${ }^{18}$. If we consider $y^{*}$ as a reference group's income, why might women's reference group's earnings be lower than men's? One possible explanation might be the effects of discrimination and occupational segregation. That is, few female role models, lower opportunity for female promotion and women being crowded into part time, low paying work, within relatively few occupations, may result in the majority of female workers observing comparable workers maintaining a similar career path to themselves. Their reference group's income will therefore be lower than comparable males who observe a male environment characterised by higher wages, promotion prospects and role models.

Following on from the above arguments, a third explanation for the gender effect in job satisfaction relies on differing personal and job characteristics of male and female workers. If a gender effect is present in characteristics such as age, education, hours of work, establishment size and occupation, this may help to explain a gender effect in job satisfaction.

The final explanation put forward for the difference in male and female levels of job satisfaction is based upon sample selectivity. It is widely recognised in the literature on gender salary differentials that participation rates may have an effect on the characteristics of women in the workplace which should be taken into account in analysis. In the present context, the argument is that female workers who have low levels of job satisfaction find it easier to leave the market place than equally unsatisfied male workers. As a result, the remaining females will have a higher average job satisfaction, as the sample is now biased. The observed pattern of gender differences is, therefore, simply the result of sample selectivity.

To what extent has previous research cast light on these various explanations? Clark (1997) finds a significant effect of including 'work values', or worker's reports of what factors are important in their job, on job satisfaction. More specifically, an emphasised importance of pay is associated with lower reports of job satisfaction and emphasis on relations at work with higher reports of job satisfaction. Work values do not, however, help to explain the gender

\footnotetext{
${ }^{17}$ Education and occupation may all have similar effects on male workers, but with the historically lower emphasis on female education and the traditional crowding of female workers into lower paid jobs it is argued that these effects will be more exaggerated for women than for men.
} 
effect in job satisfaction, which remains unchanged. As for sample selection, both Clark (1997) and Sloane and Williams (1996b) find that when a sample selection term was included in job satisfaction equations it was insignificant ${ }^{19}$.

A variety of personal job characteristics are found to vary with gender and have significant effects on the levels of job satisfaction. Clark (1997) reports that only for job satisfaction with job security and initiative does this array of controls explain the higher reports of job satisfaction by women. Sloane and Williams (1996b), in contrast, found that were women to be placed in jobs with male attributes, their level of job satisfaction would decline and become similar to that of men.

Although it is difficult to test equation (1) empirically through uncertainty about exactly what determines $y^{*}$, most studies have found some effect of comparison pay on job satisfaction. Hamermesh (1977) concludes that much of the differential in (dis)satisfaction is due to individuals' comparison of their present job with benchmark opportunities open to them. Sloane and Williams (1996b) find that both absolute and comparative income have a significant effect on the job satisfaction of men and women, although the effect is stronger for men. Interestingly, subjective measures outweigh objective measures, which adds further weight to the argument for using this type of information in economic analysis. Work by Clark (1995, 1996, 1997) and Clark and Oswald (1996) provides some evidence that women's expectations may be affected by age, education and occupation. The job satisfaction differential is found to rise with age, (with the youngest female workers reporting the same job satisfaction levels as their male counterparts) to decline with higher occupational categories, (with professional women reporting satisfaction levels similar to men) and to decline with rising levels of education, (with the female workers with highest levels of education experiencing job satisfaction levels similar to equivalently educated male workers). The gender differential is also found to be lowest for those following their career or working in order to be able to afford the essentials in life, and the highest for those working simply for themselves and their own personal reasons.

\footnotetext{
${ }^{18}$ Women's traditional role in society as homemakers may therefore affect female expectations.

${ }^{19}$ This implies that the sample is not unrepresentative of the female population. Care must be taken, however, that this result is not simply due to mis-specification of the probit function.
} 
The implications of these latter findings is that the gender job satisfaction gap may be seen as a transitory phenomenon. As workers move up their career ladders and as, presently younger workers, get older we should observe a convergence of female to male levels of job satisfaction.

\section{THE DATA}

A problem facing the researcher wishing to study the academic profession in the UK is the lack of available data. National statistics, collected by the Universities Statistical Record and later by the Higher Educational Statistics Agency, contain only very limited information. The data used in this paper come from a unique cross section study collected by the authors, using a postal questionnaire, of five Scottish Universities: Aberdeen, Dundee, Glasgow, Heriot-Watt and St. Andrews undertaken in 1995/6. It encompasses detailed information on the personal and working history of 900 academics. The average response rate achieved was 30\%, reasonably high for this type of study (Court (1994), for example, achieved a $21 \%$ response rate). Data were weighted for non-response at a faculty and rank level by sex. Academic staff was taken to include professors, senior lecturers and lecturers, research and teaching fellows and assistants. By collecting data through the use of a postal questionnaire and the careful designing of questions, very detailed information concerning individual productivity and career history was collected. Indeed, data collection with this type of detail is rarely possible at a national level and to the authors' knowledge, no other data has been collected for British academics.

The dataset contains detailed information concerning job satisfaction. Initially individuals were asked about their current job satisfaction with nine elements of their job: promotion prospects, salary, relations with their head of department, relationship with their colleagues, job security, opportunity to use their own initiative, the ability and efficiency of their head of department, the actual work undertaken and the hours of work. They were asked to rate this job satisfaction on a seven point scale where a value of one corresponded to 'not at all satisfied', a value of 7 corresponded to 'completely satisfied' and the integers from 2 to 6 represented intermediate levels of satisfaction. The final question asked was: 'All things considered, how satisfied or dissatisfied are you with your present job overall?' Individuals responded using the same seven point scale as before. 


\section{LEVELS OF JOB SATISFACTION AMONG ACADEMICS}

Table 1 presents the mean reported levels of job satisfaction across the sample, by female academics and then by male. Considering the whole sample first, results show that academics are most satisfied with the opportunity to use their own initiative, with the relationship with their colleagues and with the actual work they undertake. Academics are least satisfied with promotion prospects and salary. These results correspond with the pattern of satisfaction for workers overall reported by Clark (1997) using the BHPS and Sloane and Williams (1996b) using the Social Change and Economic Life (SCELI) dataset. In the distribution of their reports of job satisfaction at least, academics are therefore no different from the wider labour force.

Perhaps more interesting are the results by gender, presented in the first two columns of table 1 and, as a percentage response across the seven point scale, in figure 1. Unlike the studies of job satisfaction undertaken on the U.K working population as a whole, reports of overall job satisfaction and a number of its components do not vary widely by gender. The last three columns of table 1 represent the results of three tests on the significance of the gender gap in reports of job satisfaction. Only with reports of job security, salary and promotion prospects does there appear to be a significant gender differential, and in two of these three cases, the female average is lower than the male.

This result is not as surprising as it at first appears. According to the arguments presented earlier, with a highly educated workforce such as the academic profession, the gender gap in job satisfaction might be expected to disappear. Female workers may have expectations about their job that are more comparable to their male counterparts as a result of their similar levels of education than in the wider working population. The greater proportion of female academics on short term contracts and on the lower rungs of an academic career and the smaller proportion of female than male academics that consider themselves underpaid in the dataset might offer explanations for the revealed gender differences in the components of job satisfaction. These gender differences are considered in detail later in this paper.

Tables 2 and 3 represent the percentage of academics highly satisfied and highly dissatisfied respectively with both aspects of their job and overall job satisfaction, where highly satisfied is 
defined as reports of job satisfaction at the level of 6 or 7 and highly dissatisfied reports at the level of 1 or 2 on the 7 point scale. Considering reports by the whole sample first, results show that nearly three quarters of academics are highly satisfied with the opportunity to use their own initiative and over half are highly satisfied with their relationship with colleagues. Given that most academics determine their own area of work and that work is often collaborative with other specialists these results are suggestive of a productive working environment. In contrast, only $14 \%$ of academics are highly satisfied with salary and $13 \%$ with promotion prospects, or looking at this from a different angle (given in table 3), between a quarter and a third of the academic labour force are highly dissatisfied with job security, promotion prospects and salary.

Analysing these statistics by gender, we again find very similar reports for men and women in all aspects of job satisfaction apart from promotion prospects and job security where a significantly smaller proportion of women than men are highly satisfied and a significantly larger proportion of women than men are highly dissatisfied, and salary, where women are more likely to be highly dissatisfied. Table 3 also suggests that a larger proportion of women than men are highly dissatisfied with hours of work and the relationship with their head of department.

To gain an idea of how the different types of job satisfaction are correlated with overall job satisfaction for male and female academics we can run OLS regressions of overall job satisfaction on the other eight ${ }^{20}$ measures for men and women separately ${ }^{21}$. Results of this analysis are presented in table 4 . For both male and female academics, the most important determinant of overall job satisfaction is an individual's satisfaction with the work they undertake. Most academics face several years of extended degree study before securing their first post and this high investment in human capital, measured both in terms of time and foregone earnings is suggestive of commitment to the type of work undertaken in academia.

\footnotetext{
${ }^{20}$ Two of the facets of job satisfaction - the ability and efficiency of head of department and relationship with head of department - were found to be highly correlated. Only the latter was therefore included in regression analysis.

${ }^{21}$ It is suggested that OLS regression using variables with ordered scales such as our various measures of job satisfaction may produce biased results (Sloane and Williams 1996b). In order to overcome this problem, responses are rescaled to produce $\mathrm{z}$ scores measuring the number of standard deviations between a given response and the mean response.
} 
The importance of publication and reputation in an academic's career most likely reinforces this effect.

Satisfaction with promotion, salary, hours and the opportunity to use one's own initiative appear to be more important to men than women in explaining overall job satisfaction, as indicated by the higher coefficients on these variables and by the low significance of the these variables in the female equation ${ }^{22}$. In contrast, satisfaction with job security and relationship with colleagues appears to be more important for women than men in explaining overall satisfaction. Again this is indicated by the difference in coefficient size and by the insignificance of the job security variable for men. These results are interesting as they give us an idea of what characteristics of an academic career would need to be focused on in order to make academic jobs more satisfying.

Unique to the academic profession is the effect uncovered by the results for satisfaction with job security. This component of job satisfaction is found to be more important for female workers than male, the reverse of the gender effect in the UK labour force as a whole. Again, possible explanations for this effect are the higher proportion of female workers on short term contracts in this labour market and the greater reward to mobility for male academics discussed in a later section of this paper.

\section{Ordered Probit analysis - Overall Job Satisfaction}

To analysis further the determination of academic's overall job satisfaction and to investigate the gender differences in salary, promotion and job security an ordered probit approach was adopted $^{23}$. This model was chosen as the most appropriate given the ordinal nature of the job satisfaction variables. The first stage in this type of analysis is frequently to estimate probit participation equations in order to correct for sample selectivity. In the present study, however, the lack of data on individuals not currently in the workforce rendered this approach unworkable. The inability to correct for sample selectivity is not seen as a major problem

\footnotetext{
${ }^{22}$ This is in line with the findings of Clark (1997) and Sloane and Williams (1996a).

${ }^{23}$ For a brief outline of the various alternative methods for analysing job satisfaction measured on ordinal scales see Sloane and Williams (1996b).
} 
however, given the homogeneous nature of the academic labour force and that previous studies using this approach have found selectivity correction variables to be insignificant.

Following the earlier analysis the included variables are as follows. First, a series of variables are included in order to capture the effect of different attitudes or 'tastes' between male and female academics concerning what factors are important in their job. These are derived from questions concerning the importance of various aspects of an academic job and the advantages and disadvantages of an academic career over the alternatives available to a particular individual $^{24}$. As university staff are generally regarded as low-paid given their qualifications these variables also allow us to test whether the non-pecuniary advantages of employment can compensate for unfavourable pay.

A measurement of comparative pay is also included to test whether academics' reported job satisfaction is influenced by perceptions of colleagues' salaries or salaries available in the nonacademic sector. A measure of comparison income may be obtained as the deviation of actual from expected earnings, calculated as the residual from a human capital earnings equation. Various problems with this type of analysis have been encountered in earlier studies ${ }^{25}$. In the present study the available data allow us to contrast not only the effect of absolute and objective pay comparisons on reported academic job satisfaction but also subjective pay comparisons based on perceptions of deserved levels of pay. Three different measures of comparison pay are therefore considered. A measure of objective pay comparison is obtained as the difference between actual salary and predicted salary. Estimates from human capital salary regressions are used to predict salaries for academics. Two estimates of subjective pay comparison are adopted. The first is calculated as the difference between actual and deserved

\footnotetext{
${ }^{24}$ Individuals are asked to identify the importance of a series of factors such as location and working environment as components of their job choice and as factors within their current job. A separate question asks them to identify the advantages and disadvantages of their present career over any feasible alternatives.

${ }^{25}$ Hamermesh (1977) and others have pointed out the following potential problems with this approach:

1) Part of the residual from the human capital regression may reflect unmeasured variables, such as differences in ability, which may bias estimates in job satisfaction equations towards zero.

2) Part of the residual from the human capital regression may reflect omitted variables with a resulting bias on estimates in job satisfaction equations of indeterminate direction.

3) The significance of the residual in the satisfaction equation might reflect mis-specification.

In the present study, particular attention was given to the design of questions at the data collection stage in order to try and reduce any bias resulting from omitted variables or measurements errors. It is unlikely however, that these problems have been overcome completely.
} 
pay $^{26}$, the second is obtained from reported underpayment ${ }^{27}$. The effect of actual pay on job satisfaction is also captured by the inclusion of the log of salary.

Finally, personal and job characteristics variables are included for both men and women to catch any gender effect present in characteristics such as age ${ }^{28}$, education, department size, faculty affiliation, university or current job which may help to explain gender differences in components of job satisfaction.

The results of the ordered probit analysis ${ }^{29}$ on the determinants of overall job satisfaction are given in table 5. Regressions were run for the dataset as a whole, and for males and females separately ${ }^{30}$. Results from the former reveal an insignificant gender difference in overall job satisfaction, represented by the insignificant gender dummy variable which is confirmation of the result suggested by summary statistics. Analysis using the different measures of comparison income reveals the dominant influence of subjective measures over objective ${ }^{31}$. Both variables measuring personal and job characteristics and those capturing attitudes or 'tastes' have a significant effect on overall job satisfaction.

\footnotetext{
${ }^{26}$ Where individuals state their deserved salary in response to the question "In your view, what salary do you deserve to receive per annum?". See variable list for variable definition.

${ }^{27}$ Individuals are asked to indicate, all things considered, which of the following statements best described their present salary: Much less than I deserve; Somewhat less than I deserve; About what I deserve; Somewhat more than I deserve; Much more than I deserve.

${ }^{28}$ The academic profession exhibits a strong cohort effect. The older academics in the dataset experience a very different profession today to the one that they entered. Many will have observed the implementation of Sex Discrimination legislation in the 1970s and the increase in competition within the profession with the onset of the research assessment exercises and the increase in short term contracts. In addition to this, in the days of the eldest cohort of academics in the dataset, women academics were rare and lower academic standards may have been expected of them. Today, however, we find a much higher proportion of women working to the same standards as those expected of men. As a consequence of this, the older academics in the dataset will most likely have required less in the way of formal qualifications, for example, than those entering the labour market now. The majority of women in the profession however are young women who differ in their characteristics from the characteristic of the average male in the dataset. Various specifications for age to account for this cohort effect were considered. A split in the dataset at age 35, represented in analysis through the use of a dummy variable for age 36 and over, appears to fit the data best and corresponds to that used by HESA.

${ }^{29}$ All variables are introduced to the model specification in a stepwise manner, the significant of each variable being tested at each stage.

${ }^{30}$ Analysis of men and women separately is undertaken despite the existence of an insignificant gender gap in overall job satisfaction in order to unearth any differences in the way male and female overall job satisfaction is determined. Indeed, likelihood ratio tests reveal that the log likelihood is significantly lower with separate regressions.

${ }^{31}$ In accordance with Sloane and Williams (1996b).
} 
Considering the results by gender, we find a positive effect of absolute salary on overall job satisfaction for male academics, although the effect is not significant, but a significantly negative effect for female academics. This strange result implies that the higher the pay of female academics the less satisfied they become! The coefficient on the number of discretionary awards is also significantly negative. Monetary payment therefore negatively influences female overall job satisfaction. Given that seniority, age, ability and job characteristics are controlled for, one remaining possible explanation for this unusual result is the slower promotion rate of women. The number of promotions received has a strong positive effect on female job satisfaction. This problematic result suggests, therefore, a compensating differential (in the form of salary and discretionary reward) which is not compensating enough for differential male and female promotion opportunity ${ }^{32}$.

Focusing on the pay comparison measures in table 5, individuals who consider themselves underpaid report lower levels of job satisfaction. A negative coefficient is found in both the male and female regressions, although the effect is only significant for men. It would therefore appear that men are more concerned about their relative income than women. Neither the objective - the difference between actual and predicted pay - or the subjective comparison measure - the difference between deserved and predicted pay used by Sloane and Williams (1996(a) and (b)) were found to be significant and are not reported for results run separately by gender ${ }^{33}$. This suggests that academics may place a lower emphasis on pecuniary relative to non-pecuniary aspects of work than other sections of the workforce.

Those academics who stress the importance of good working relationships with colleagues, the importance of teaching and the specialisation of their department, the advantages of the opportunity to undertake interesting work in a relaxing work environment and the opportunity for travel have significantly higher job satisfaction than those who do not rate these factors as important. The non-pecuniary advantages of employment therefore compensate for unfavorable pay for these individuals. Conversely those who cite a lower opportunity for promotion as a disadvantage and who regard academic employment as removed from the real

\footnotetext{
${ }^{32}$ Women are in a rank longer. That is, male are promoted faster than females. To investigate this conjecture further another regression of overall job satisfaction was undertaken with interaction terms between salary and rank. Results from this analysis are presented in table 6 . The positive coefficients on the male interaction terms, but negative coefficients on the female interactions provide some support for this hypothesis.
} 
world report significantly lower overall job satisfaction. The joint significance of these variables points to the attitudes and tastes of academics as an important determinant of their overall job satisfaction.

Several other features are worthy of comment. First, those academics employed in the University of St. Andrews (the excluded category) ${ }^{34}$ are significantly more satisfied with their work than their colleagues elsewhere. Location is especially important for women's job satisfaction. This suggests, therefore, that there may be some self selection in terms of the choice of employment according to University. Second, for men, the older and more senior academics report lower levels of overall job satisfaction, whereas for women, both these effects are positive. This provides mixed evidence for the hypothesis proposed in the introductory paragraphs for job satisfaction increasing with age. It does however lend further support to the promotion vs. salary argument for females' overall job satisfaction. Third, unemployment and previous non-academic work boosts the overall job satisfaction of both male and female academics. This suggests that time away from the academic labour market for both men and women lowers an individual's income expectations and therefore boosts the utility derived from their current position. Unemployment may also reduce income expectations. Finally, job satisfaction varies by faculty. For women, the engineers (the excluded category) are significantly more satisfied than those in the other faculties, the least satisfied being the social scientists. For men, the social scientists are the most satisfied and the scientists the least.

\section{Ordered Probit analysis - Components of Job Satisfaction}

Summary statistics have revealed a significant gender difference in academics' reported job satisfaction with promotion prospects, salary and job security. The final analysis in this paper therefore turns to investigation of these individual facets of overall job satisfaction. Since analysis of the determinants of satisfaction for academics is original, the specifications between

\footnotetext{
${ }^{33}$ This result is consistent for all ordered probit analysis undertaken. Results from this point onwards therefore only present the subjective measure of comparison pay derived from respondents reports of underpayment.

${ }^{34}$ Who according salary equations are paid more than their colleagues in the four other Scottish Universities in this study.
} 
models of the components of overall job satisfaction were allowed to vary in order to investigate exactly what variables are important for the determination of each type of job satisfaction for this professional group. The reported regression specifications were therefore generated through a sequence of nested tests. All variables are introduced to the ordered probit specification in a stepwise manner, the significant of each variable being tested by likelihood ratio test at each stage. Likelihood ratio tests of the final specification lead to the rejection of the null hypotheses that any of the alternative category coefficients are equal to zero.

\section{Promotion Prospects}

Table 7 presents the results of the analysis of the determinants of job satisfaction with promotion prospects for all academics, and by gender separately. The results for the entire dataset reveal a significant gender gap in satisfaction with promotion prospects which cannot be explained fully by variables relating to comparison or absolute salary, attitudes or job characteristics.

Attitude and taste variables and variables relating to individual and job characteristics are found to have a significant impact on satisfaction with promotion prospects. A perception of being underpaid has a strong negative impact on reports of satisfaction with promotion which is significant for both men and women. Dissatisfaction with salary therefore fuels dissatisfaction with promotion prospects, perhaps as academics seek to compensate for the former with higher promotion expectations ${ }^{35}$. Rank, as one might expect, is a particularly powerful determinant of this type of job satisfaction with professors reporting significantly higher levels of job satisfaction with promotion. Differential promotion opportunities by men and women can again be suggested tentatively as an explanation for the perpetual gender gap. The fact that reported satisfaction with promotion prospects is not significantly influenced by faculty or university variables, would seem to suggest that national influences are more important than institution specific or subject specific effects.

\footnotetext{
${ }^{35}$ Comparison of results for men and women, as with results for overall satisfaction, reveal a positive sign when salary is regressed on male satisfaction with promotion, but a negative one on female satisfaction with promotion prospects, although neither is significant.
} 
An interesting finding is that for men and women alike, although the effect of seniority is positive, older academics report lower levels of job satisfaction with promotion prospects. This result most likely reflects the nature of an academic career. Those who achieve promotion report higher levels of job satisfaction, but those that have not yet achieved promotion to their ultimate rank perceive their dwindling promotion opportunities as they get older and voice lower job satisfaction with promotion prospects. The cohort effect found in the academic labour market offers an alternative explanation of this age effect. Older academics who entered academic life in an environment with relatively more promotion opportunities may now experience limited promotion opportunities as the academic profession becomes more competitive.

Finally, academics on short term contracts report significantly lower levels of job satisfaction with promotion prospects. Thus, as hypothesised, the significantly larger number of female academics on this type of contract is an important explanatory factor in the explanation of the raw gender differential.

\section{Job security}

The results for reported satisfaction with job security are presented in table 8 . The gender gap is fully explained by inclusion of variables relating to comparison and absolute salary, attitudes and job characteristics ${ }^{36}$.

The effect of absolute salary is significantly positive and the effect of comparison income negative for both men and women, although the latter effect is only significant for women. An individual's climb up the rungs of a salary scale therefore positively affects his or her perceptions of job security. For a female academic however, this effect is tempered by comparison of her relative salary position.

Factors that might constrain or disrupt a future career are found to have a negative effect on both male and female satisfaction with job security. For example, academics working in a small department and those that consider academic life removed from the real world to be a

\footnotetext{
${ }^{36}$ Consistent with the findings of Clark (1997).
} 
disadvantage report lower levels of satisfaction with job security. Characteristics of an academic's position or attitudes which signal that they are good at their job, however, have a positive effect on satisfaction with job security. The number of discretionary awards received, and considering the opportunity to hold responsibility an advantage of an academic career has a positive effect on this component of job satisfaction for both men and women.

The strongest influence on job security, however, as anticipated, is the effect of working on a short term contract. Male and female academics on short term contracts report significantly lower satisfaction with job security, although the effect is particularly pronounced for women. The significantly larger number of female academics on short term contracts is therefore an important contributing factor explaining the raw gender differential. The effect of short term contracts is compounded for female academics by the negative influence of the number of posts held on their reported satisfaction with job security. This is an interesting finding as it suggests that an increase in the number of posts held, rather than securing a female academics' position, as in the case of male academics and their promotion opportunities, actually succeeds in weakening it. The effect of rank on satisfaction with job security, however, is a positive one, lecturers, senior lecturers and professors report successively higher satisfaction with job security over the excluded variable researcher although the effect is only significant for male academics. Given that the majority of female academics are on the lower rungs of an academic career this finding is also an important explanation for the aggregate gender gap in satisfaction with job security reported in table1.

Two other findings are worthy of discussion, first, those academics employed in the University of St. Andrews (the excluded category) who, we have found, have higher overall job satisfaction are also significantly more satisfied with their job security than academics at other universities. Second, working in the faculties of social science and arts have a positive effect on reported job satisfaction for women while females working in the faculty of engineering report significantly lower levels of job security. In contrast, males working in both the faculties of social science and engineering have higher satisfaction than workers in the arts. These latter results tentatively suggest problems for women in male dominated areas. 


\section{Salary}

Finally, we turn to consideration of an academic's satisfaction with salary (see table 10). Results of the ordered probit analysis reveal a gender difference in salary that is no longer significant. The gender difference in salary satisfaction revealed by summary statistics is therefore explained by variables included in the model. Results do not vary by university of current employment which suggests that we are capturing an occupational rather than institutional effect.

Although salary is positively related to job satisfaction for both men and women, its effect is only significant for men. The most striking finding uncovered is the large negative coefficient on the comparison pay variable. Individuals' comparisons of their pay provide the largest influence on reports of current job satisfaction with salary. The fact that subjective outweigh objective measures suggests that academics compare a wider group than just other academics when evaluating their pay. The larger coefficient for males reinforces the earlier finding that men are more concerned about the pecuniary aspects of their job than women. The relationship between satisfaction with salary and promotion is reemphasised by the significantly negative influence of acknowledging promotion disadvantages of academic employment.

The negative effect of the variable TEACHER on satisfaction with salary is interesting and suggests that those individuals whose job is predominantly teaching based report substantially lower levels of satisfaction with their salary. Universities have increasingly become accused of rewarding research specialisation above teaching, particularly with the implementation of research assessment exercises, and this result would seem to present evidence of this effect. Some of this negative effect is counterbalanced by academics stressing the importance of the opportunity to teach and of good relationships with colleagues to them in their choice of job. This provides some evidence of the non-pecuniary advantages of employment compensating for unfavourable pay.

The results of the analysis of academic's satisfaction with salary are also suggestive of a differential reward to publication by gender. Here we find that although increased publication has a significantly positive effect on male satisfaction with their salary, its effect on female 
satisfaction is significantly negative. The simplest explanation for this finding is that females are not being sufficiently rewarded for their publication.

Two further effects are worthy of note. First, older and more senior male academics report lower levels of job satisfaction with salary, whereas for women, both these effects are positive. This result might be explained by lower female income expectations boosting the utility derived from their current position ${ }^{37}$. Finally, academics in the faculty of engineering are most satisfied with their pay.

\section{CONCLUSION}

This study finds that levels of overall job satisfaction among academics are high, though not with pay and promotion. The inclusion of a range of variables about aspects of work not available in other studies suggests that academics trade-off pecuniary and non-pecuniary elements of work. It has been observed that job satisfaction generally declines with level of education (Clark and Oswald 1995 and Sloane and Williams 1996(a) and (b)). Given also that British academics are relatively low paid ${ }^{38}$ with fairly limited promotion prospects, given their qualifications, one would expect to find a low level of overall job satisfaction among this group. In fact the recorded level of overall job satisfaction does not appear to be out of line with that recorded for other groups, which is consistent with self selection into academic jobs by individuals who place a relatively high ranking on non-pecuniary aspects of work.

Unlike many earlier studies we also find that there are no significant differences between men and women in overall levels of job satisfaction, although women report lower levels of satisfaction with promotion prospects, salary and job security. Ordered probit analysis suggests this is the result of a large proportion of women being hired on short term contracts and on the lower rungs of employment in the academic labour force, among other effects. The gender difference in satisfaction with promotion prospects cannot fully be explained by variables included in the model. Results tentatively suggest that lower female opportunity for promotion may be influential. The finding that the determinants of job satisfaction differ according to

\footnotetext{
${ }^{37}$ Lower female income expectations may arise through the lower female opportunity for promotion discussed in chapter 6, the male domination of academia, or the age effects discussed in section 7.2.

${ }^{38}$ National Committee of Inquiry into Higher Education (1997)
} 
gender make it more difficult to implement changes that would raise overall job satisfaction amongst the academic workforce.

Pay comparisons within the academic profession do appear to influence the level of overall job satisfaction $^{39}$ although the effect is stronger for men than women. Subjective pay comparisons outweigh objective which suggests that academics have regard to groups other than just academics in evaluation of their relative pay position. Neither objective or subjective pay comparisons as used in previous studies of job satisfaction are significant however, which suggests that academics may, indeed, be an idiosyncratic group.

\footnotetext{
${ }^{39}$ Watson et al (1996) also find for managers that comparison pay matters more than absolute pay in
} determining job satisfaction. 
VARIABLE LIST

\begin{tabular}{|c|c|c|c|}
\hline & & \multicolumn{2}{|c|}{ Means } \\
\hline Variable & Definition & Female & Male \\
\hline ABERDEEN & $=1$ if respondent works in the university of Aberdeen, $=0$ otherwise. & .124 & .178 \\
\hline ADVINTWK & $\begin{array}{l}=1 \text { if respondent considers interesting work an advantage of academia, }=0 \\
\text { otherwise. }\end{array}$ & .903 & .891 \\
\hline ADVRESP & $\begin{array}{l}=1 \text { if respondent considers the opportunity to hold responsibility an } \\
\text { advantage of academia, }=0 \text { otherwise. }\end{array}$ & .485 & .403 \\
\hline ADVTRAVE & $\begin{array}{l}=1 \text { if respondent considers the opportunity to travel an advantage of } \\
\text { academia, }=0 \text { otherwise. }\end{array}$ & .511 & .525 \\
\hline ADVWKENV & $\begin{array}{l}=1 \text { if respondent considers a relaxed working environment an advantage of } \\
\text { academia, }=0 \text { otherwise. }\end{array}$ & .509 & .487 \\
\hline AGE36OVR & $=1$ if respondent is over the age of $36,=0$ otherwise. & .390 & 695 \\
\hline ARTS & $=1$ if respondent works within the faculty of arts, $=0$ otherwise. & .164 & .178 \\
\hline DISCREC & Number of discretionary awards received in total. & .304 & .645 \\
\hline DISPROM & $\begin{array}{l}=1 \text { if respondent considers a smaller opportunity for promotion a } \\
\text { disadvantage of academia, }=0 \text { otherwise. }\end{array}$ & .434 & .384 \\
\hline DISREAL & $\begin{array}{l}=1 \text { if respondent considers a closed environment, removed from the real } \\
\text { world a disadvantage of academia, }=0 \text { otherwise. }\end{array}$ & .196 & .108 \\
\hline DISSAL & $\begin{array}{l}=1 \text { if respondent considers a low salary a disadvantage of academia, }=0 \\
\text { otherwise. }\end{array}$ & .587 & .705 \\
\hline DUNDEE & $=1$ if respondent works in the university of Dundee, $=0$ otherwise. & .337 & .182 \\
\hline FULLTIME & $=1$ if respondent works over 30 hours per week, $=0$ otherwise. & .893 & .958 \\
\hline GLASGOW & $=1$ if respondent works in the university of Glasgow, $=0$ otherwise. & .337 & .357 \\
\hline HERIOTWT & $=1$ if respondent works in the university of Heriot-Watt, $=0$ otherwise. & .018 & .101 \\
\hline JOB1PRIV & $=1$ if respondents' last job was in the private sector, $=0$ otherwise. & .020 & .096 \\
\hline JOB1SCOT & $\begin{array}{l}=1 \text { if respondent's last job was in a Scottish higher education institution, }=0 \\
\text { otherwise. }\end{array}$ & .245 & .241 \\
\hline LECTRER & $=1$ if respondent is a lecturer, $=0$ otherwise. & .320 & .353 \\
\hline LOGSAL & Log of respondent's annual salary. & 9.924 & 10.195 \\
\hline MED & $=1$ if respondent works within the faculty of medicine, $=0$ otherwise. & .453 & .205 \\
\hline NOPROMOT & Number of promotions received. & .336 & .832 \\
\hline NUMPOSTS & Number of posts held over working life. & 3.63 & 3.40 \\
\hline PRECHANG & $\begin{array}{l}=1 \text { if household responsibilities have ever prevented the respondent from } \\
\text { changing job, }=0 \text { otherwise. }\end{array}$ & .225 & .227 \\
\hline PREDA & $\begin{array}{l}\text { Objective measure of comparison pay. Derived from taking the difference } \\
\text { between the log of individual's actual salary and predicted salary. Estimates } \\
\text { from human capital salary regressions are used to predict salaries. }\end{array}$ & -.020 & -.009 \\
\hline PREJOB2 & $\begin{array}{l}=1 \text { if household responsibilities have ever prevented the respondent from } \\
\text { taking a second job, }=0 \text { otherwise. }\end{array}$ & .036 & .041 \\
\hline PROFFOR & $=1$ if respondent is a professor, $=0$ otherwise. & .025 & .220 \\
\hline PUBPAPS & Number of papers published by respondent in total. & 7.79 & 32.38 \\
\hline RECCHANG & $\begin{array}{l}=1 \text { if household responsibilities have ever required the respondent to } \\
\text { change job, }=0 \text { otherwise. }\end{array}$ & .113 & .039 \\
\hline SALLECT & SUBCOMP1*LECTRER & 3.70 & 3.240 \\
\hline SALPROF & SUBCOMP1*PROFFOR & .274 & 2.138 \\
\hline SALSEN & SUBCOMP $1{ }^{*}$ SENREAD & .989 & 2.573 \\
\hline SCIENCE & $=1$ if respondent works within the faculty of science, $=0$ otherwise. & .166 & .294 \\
\hline SCOTDEG1 & $\begin{array}{l}=1 \text { if respondent gained their first degree at a Scottish higher education } \\
\text { institution, }=0 \text { otherwise. }\end{array}$ & .518 & .450 \\
\hline SENREAD & $=1$ if respondent is a senior lecturer or reader, $=0$ otherwise & .102 & .257 \\
\hline SEX & $=1$ if male, $=0$ if female. & & \\
\hline SHORTERM & $=1$ if respondent is on a short term contract (defined as up to three years). & .602 & .234 \\
\hline SIZE1 & $\begin{array}{l}=1 \text { if the number of academic staff in the respondent's department is less } \\
\text { than } 10,=0 \text { otherwise. }\end{array}$ & .231 & .203 \\
\hline SOCSCI & $=1$ if respondent works within the faculty of social science, $=0$ otherwise. & .164 & .167 \\
\hline STANDREW & $=1$ if respondent works in the university of St. Andrews, $=0$ otherwise. & .195 & .191 \\
\hline SUBCOMP1 & $\begin{array}{l}\text { Subjective measure of comparison pay. Derived from response of } \\
\text { individuals to a question "All things considered, which of the following } \\
\text { statements do you feel best describes your present salary?" } \\
=1 \text { for respondents who replied "Much less than I deserve", =0 otherwise. }\end{array}$ & .136 & .175 \\
\hline
\end{tabular}




\begin{tabular}{|c|c|c|c|}
\hline TEACHER & $=1$ if respondent's current position is primarily teaching based. & .011 & .004 \\
\hline UNDR1 & $\begin{array}{l}\text { Subjective measure of comparison pay. Derived from taking the difference } \\
\text { between the log of individual's actual salary and the log of their deserved } \\
\text { salary (derived from individual's statements of their deserved salary) and } \\
\text { creating a dummy variable }=1 \text { for those individuals in the 3rd and 4th } \\
\text { quartiles of underpayment, }=0 \text { otherwise. This is the subjective measure of } \\
\text { comparison pay which has been used in various forms in previous papers } \\
\text { on job satisfaction. }\end{array}$ & .279 & .356 \\
\hline UNEMPLOY & $=1$ if respondent has been unemployed, $=0$ otherwise. & .222 & .157 \\
\hline ZIMPCOLL & $\begin{array}{l}\text { Standardised score of the importance of good relationship with colleagues } \\
\text { to an individual in their current job where importance is measured on a } \\
\text { seven point scale of } 1=\text { not at all important to } 7=\text { very important. }\end{array}$ & & \\
\hline ZIMPENVR & $\begin{array}{l}\text { Standardised score of the importance of a pleasant working environment to } \\
\text { an individual in their current job where importance is measured on a seven } \\
\text { point scale of } 1=\text { not at all important to } 7=\text { very important. }\end{array}$ & & \\
\hline ZIMPHR1 & $\begin{array}{l}\text { Standardised score of the importance of flexible working hours to an } \\
\text { individual in their current job where importance is measured on a seven } \\
\text { point scale of } 1=\text { not at all important to } 7=\text { very important. }\end{array}$ & & \\
\hline ZIMPSPEC & $\begin{array}{l}\text { Standardised score of the importance of the research specialisation of a } \\
\text { department to an individual in their last choice of job where importance is } \\
\text { measured on a seven point scale of } 1=\text { not at all important to } 7=\text { very } \\
\text { important. }\end{array}$ & & \\
\hline ZIMPTEAC & $\begin{array}{l}\text { Standardised score of the importance of the opportunity to teach to an } \\
\text { individual in their last choice of job where importance is measured on a } \\
\text { seven point scale of } 1=\text { not at all important to } 7=\text { very important. }\end{array}$ & & \\
\hline ZSATCOLL & $\begin{array}{l}\text { Standardised score of an individuals' job satisfaction with his/her } \\
\text { relationship with colleagues, where job satisfaction is measured on a seven } \\
\text { point scale of } 1=\text { not at all satisfied to } 7=\text { very satisfied. }\end{array}$ & & \\
\hline ZSATHEAD & $\begin{array}{l}\text { Standardised score of an individuals' job satisfaction with the relationship } \\
\text { with his/her head of department, where job satisfaction is measured on a } \\
\text { seven point scale of } 1=\text { not at all satisfied to } 7=\text { very satisfied. }\end{array}$ & & \\
\hline ZSATHOURS & $\begin{array}{l}\text { Standardised score of an individuals' job satisfaction with his/her hours of } \\
\text { work, where job satisfaction is measured on a seven point scale of } 1=\text { not } \\
\text { at all satisfied to } 7=\text { very satisfied. }\end{array}$ & & \\
\hline ZSATINIT & $\begin{array}{l}\text { Standardised score of an individuals' job satisfaction with the opportunity to } \\
\text { use his/her own initiative, where job satisfaction is measured on a seven } \\
\text { point scale of } 1=\text { not at all satisfied to } 7=\text { very satisfied. }\end{array}$ & & \\
\hline ZSATPROM & $\begin{array}{l}\text { Standardised score of an individuals' job satisfaction with his/her promotion } \\
\text { prospects, where job satisfaction is measured on a seven point scale of } 1= \\
\text { not at all satisfied to } 7=\text { very satisfied. }\end{array}$ & & \\
\hline ZSATSAL & $\begin{array}{l}\text { Standardised score of an individuals' job satisfaction with his/her salary, } \\
\text { where job satisfaction is measured on a seven point scale of } 1=\text { not at all } \\
\text { satisfied to } 7=\text { very satisfied. }\end{array}$ & & \\
\hline ZSATSEC & $\begin{array}{l}\text { Standardised score of an individuals' job satisfaction with his/her job } \\
\text { security, where job satisfaction is measured on a seven point scale of } 1= \\
\text { not at all satisfied to } 7=\text { very satisfied. }\end{array}$ & & \\
\hline ZSATWORK & $\begin{array}{l}\text { Standardised score of an individuals' job satisfaction with the actual work } \\
\text { they do, where job satisfaction is measured on a seven point scale of } 1= \\
\text { not at all satisfied to } 7=\text { very satisfied. }\end{array}$ & & \\
\hline
\end{tabular}


Figure 1: Gender Comparison of types of Job Satisfaction
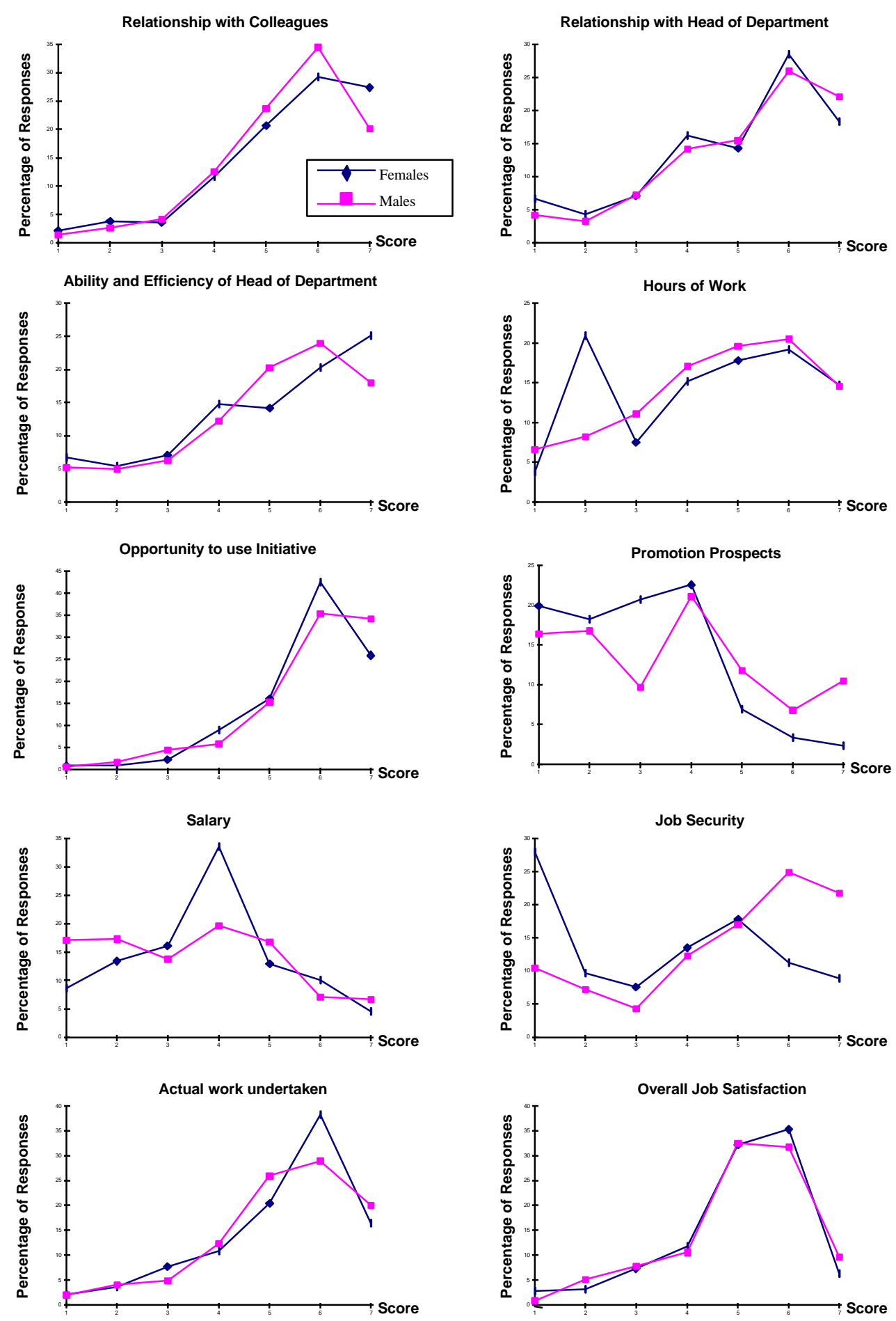
Table 1: Mean levels of Job Satisfaction

\begin{tabular}{|c|c|c|c|c|c|c|}
\hline Categories of Job satisfaction & All & Females & Males & \multicolumn{3}{|c|}{ Probabilities } \\
\hline & & & & 1 & 2 & 3 \\
\hline Relationship with Colleagues & 5.42 & 5.45 & 5.41 & 0.629 & 0.1038 & 0.1579 \\
\hline $\begin{array}{l}\text { Relationship with Head of } \\
\text { Department }\end{array}$ & 5.09 & 4.95 & 5.16 & 0.091 & 0.1928 & 0.4771 \\
\hline $\begin{array}{l}\text { Ability and Efficiency of } \\
\text { Head of Department }\end{array}$ & 4.99 & 4.98 & 4.99 & 0.956 & 0.3079 & 0.6219 \\
\hline Hours of work & 4.52 & 4.40 & 4.59 & 0.156 & 0.2642 & 0.0055 \\
\hline Opportunity to use initiative & 5.81 & 5.76 & 5.83 & 0.452 & 0.3625 & 0.0794 \\
\hline Promotion Prospects & 3.40 & 2.97 & 3.62 & $0.000^{*}$ & $0.0000 *$ & $0.0001 *$ \\
\hline Salary & 3.60 & 3.78 & 3.51 & $0.031 *$ & $0.0133 *$ & $0.0152 *$ \\
\hline Job Security & 4.41 & 3.55 & 4.84 & $0.000^{*}$ & $0.0000 *$ & $0.0000 *$ \\
\hline Actual Work Undertaken & 5.27 & 5.26 & 5.27 & 0.900 & 0.8087 & 0.9060 \\
\hline Overall Job Satisfaction & 5.04 & 5.01 & 5.06 & 0.578 & 0.9115 & 0.9975 \\
\hline
\end{tabular}

$\mathrm{H}_{\mathrm{o}}$ : The two samples come from populations having the same distribution.

$1=\mathrm{t}$-test

2= Mann-Whitney U - Wilcoxon

3= Kolmogorov-Smirnov 2 sample test

* indicates that a significant gender difference exists at the 5\% significance level.

Table 2: Percentage of highly satisfied academics

\begin{tabular}{|l|ccc|}
\hline Type of Job satisfaction & All & Females & Males \\
\hline Relationship with colleagues & 55.3 & 56.7 & 54.6 \\
Relationship with Head of Department & 47.6 & 46.8 & 48.1 \\
Ability and efficiency of Head of & 43.1 & 45.4 & 42.0 \\
Department & & & \\
Hours of work & 34.8 & 33.9 & 35.1 \\
Opportunity to use initiative & 69.2 & 68.4 & 69.5 \\
Promotion prospects & 13.4 & 5.6 & 17.3 \\
Salary & 14.1 & 14.6 & 13.8 \\
Job security & 37.9 & 20.2 & 46.7 \\
Actual work undertaken & 50.9 & 54.7 & 49.0 \\
Overall job Satisfaction & & & 41.4 \\
\hline
\end{tabular}

Highly Satisfied $=$ Score of 6 or 7 
Table 3: Percentage of highly dissatisfied academics

\begin{tabular}{|l|ccc|}
\hline Type of Job satisfaction & All & Females & Males \\
\hline Relationship with colleagues & 4.8 & 6.0 & 4.1 \\
Relationship with Head of Department & 8.6 & 11.0 & 7.5 \\
Ability and efficiency of Head of Department & 10.9 & 12.1 & 10.2 \\
Hours of work & 18.0 & 24.7 & 14.8 \\
Opportunity to use initiative & 2.3 & 1.9 & 2.4 \\
Promotion prospects & 34.8 & 38.1 & 33.2 \\
Salary & 30.3 & 22.0 & 34.4 \\
Job security & 24.3 & 37.7 & 17.7 \\
Actual work undertaken & 5.9 & 5.7 & 6.0 \\
Overall job Satisfaction & & & 5.9 \\
\hline
\end{tabular}

Highly Dissatisfied $=$ Score of 1 or 2

Table 4: OLS regression, dependent variable: Z-score of overall job satisfaction (Standard errors in Parentheses)

\begin{tabular}{|l|cc|}
\hline Variable & Females & Males \\
\hline ZSATCOLL & $.241 * * *$ & $.108^{*}$ \\
& $(.081)$ & $(.063)$ \\
ZSATHEAD & .079 & $.084 * *$ \\
& $(.060)$ & $(.043)$ \\
ZSATHOURS & .074 & $.108 * *$ \\
& $(.062)$ & $(.050)$ \\
ZSATINIT & .062 & $.148 * * *$ \\
& $(.061)$ & $(.044)$ \\
ZSATPROM & $.132 *$ & $.161 * * *$ \\
& $(.077)$ & $(.053)$ \\
ZSATSAL & .106 & $.182 * * *$ \\
& $. .076)$ & $(.056)$ \\
ZSATSEC & $.147 * * *$ & -.046 \\
& $(.057)$ & $(.058)$ \\
ZSATWORK & $.404 * * *$ & $.341 * * *$ \\
& $(.062)$ & $(.052)$ \\
CONSTANT & .030 & -.009 \\
& $(.055)$ & $(.045)$ \\
\hline No of observations & 242 & 504 \\
$\mathrm{R}^{2}$ & 0.54 & 0.53 \\
$\overline{\mathrm{R}}^{2}$ & 0.52 & 0.53 \\
Mean of Oversat & 5.01 & 5.06 \\
\hline
\end{tabular}

*** indicates significance at $1 \%$ level, $* *$ indicates significance at $5 \%$ level, $*$ indicates significance at $10 \%$ level 
Table 5: Ordered Probit regression, dependent variable: Overall job satisfaction

\begin{tabular}{|c|c|c|c|c|c|}
\hline & All & All & All & Females & Males \\
\hline SEX & $\begin{array}{l}.146 \\
(.097)\end{array}$ & $\begin{array}{l}.126 \\
(.097)\end{array}$ & $\begin{array}{l}.161 \\
(.107)\end{array}$ & NA & NA \\
\hline LOGSAL & $\begin{array}{l}-.052 \\
(.131)\end{array}$ & $\begin{array}{l}-.057 \\
(.130)\end{array}$ & $\begin{array}{l}.119 \\
(.245)\end{array}$ & $\begin{array}{l}-.452 * * \\
(.232)\end{array}$ & $\begin{array}{l}.171 \\
(.173)\end{array}$ \\
\hline $\begin{array}{l}\text { SUBCOMP1 } \\
\text { (SUBJECTIVE MEASURE OF } \\
\text { COMPARISON PAY }^{40} \text { ) }\end{array}$ & $\begin{array}{l}-.348 * * * \\
(.108)\end{array}$ & NA & NA & $\begin{array}{l}-.194 \\
(.228)\end{array}$ & $\begin{array}{l}-.440 * * * \\
(.124)\end{array}$ \\
\hline $\begin{array}{l}\text { UNDR1 } \\
\text { (SUBJECTIVE MEASURE } \\
\text { OF COMPARISON PAY }{ }^{41} \text { ) }\end{array}$ & NA & $\begin{array}{l}-.057 \\
(.084)\end{array}$ & NA & NA & NA \\
\hline $\begin{array}{l}\text { PREDA } \\
\text { (OBJECTIVE MEASURE OF } \\
\text { COMPARISON PAY) }\end{array}$ & NA & NA & $\begin{array}{l}-.161 \\
(.296)\end{array}$ & NA & NA \\
\hline ZIMPCOLL & $\begin{array}{l}.222 * * * \\
(.042)\end{array}$ & $\begin{array}{l}.231 * * * \\
(.042)\end{array}$ & $\begin{array}{l}.233 * * * \\
(.045)\end{array}$ & $\begin{array}{l}.168 * * \\
(.079)\end{array}$ & $\begin{array}{l}.270 * * * \\
(.0520\end{array}$ \\
\hline ZIMPSPEC & $\begin{array}{l}.111 * * * \\
(.042)\end{array}$ & $\begin{array}{l}.113^{* * *} \\
(.042)\end{array}$ & $\begin{array}{l}.131 * * * \\
(.0460\end{array}$ & $\begin{array}{l}.167 * * \\
(.081)\end{array}$ & $\begin{array}{l}.097 * \\
(.051)\end{array}$ \\
\hline ZIMPTEAC & $\begin{array}{l}.116^{* * * *} \\
(.043)\end{array}$ & $\begin{array}{l}.125^{* * *} \\
(.043)\end{array}$ & $\begin{array}{l}.124 * * * \\
(.047)\end{array}$ & $\begin{array}{l}.128^{*} \\
(.078)\end{array}$ & $\begin{array}{l}.123^{* *} \\
(.054)\end{array}$ \\
\hline ADVINTWK & $\begin{array}{l}.333 * * * \\
(.132)\end{array}$ & $\begin{array}{l}.308 * * * \\
(.131)\end{array}$ & $\begin{array}{l}.358 * * * \\
(.148)\end{array}$ & $\begin{array}{l}.512 * * \\
(.243)\end{array}$ & $\begin{array}{l}.400 * * * \\
(.162)\end{array}$ \\
\hline ADVTRAVE & $\begin{array}{l}.215 * * * \\
(.084)\end{array}$ & $\begin{array}{l}.216 * * * \\
(.084)\end{array}$ & $\begin{array}{l}.198 * * \\
(.091)\end{array}$ & $\begin{array}{l}.449 * * * \\
(.156)\end{array}$ & $\begin{array}{l}.117 \\
(.105)\end{array}$ \\
\hline ADVWKENV & $\begin{array}{l}.296 * * * \\
(.084)\end{array}$ & $\begin{array}{l}.289 * * * \\
(.084)\end{array}$ & $\begin{array}{l}.275 * * * \\
(.091)\end{array}$ & $\begin{array}{l}.450 * * * \\
(.161)\end{array}$ & $\begin{array}{l}.337 * * * \\
(.104)\end{array}$ \\
\hline DISPROM & $\begin{array}{l}-.463 * * * \\
(.085)\end{array}$ & $\begin{array}{l}-.500 * * * \\
(.084)\end{array}$ & $\begin{array}{l}-.532 * * * \\
(.091)\end{array}$ & $\begin{array}{l}-.503 * * * \\
(.154)\end{array}$ & $\begin{array}{l}-.504 * * * \\
(.106)\end{array}$ \\
\hline DISREAL & $\begin{array}{l}-.585 * * * \\
(.117)\end{array}$ & $\begin{array}{l}-.570 * * * \\
(.117)\end{array}$ & $\begin{array}{l}-.679 * * * \\
(.130)\end{array}$ & $\begin{array}{l}-.460 * * * \\
(.186)\end{array}$ & $\begin{array}{l}-.661 * * * \\
(.158)\end{array}$ \\
\hline ABERDEEN & $\begin{array}{l}-.242 * \\
(.147)\end{array}$ & $\begin{array}{l}-.237 * \\
(.147)\end{array}$ & $\begin{array}{l}-.275^{*} \\
(.161)\end{array}$ & $\begin{array}{l}-.950 * * * \\
(.322)\end{array}$ & $\begin{array}{l}-.172 \\
(.173)\end{array}$ \\
\hline DUNDEE & $\begin{array}{l}-.302 * * \\
(.136)\end{array}$ & $\begin{array}{l}-.285^{* *} \\
(.136)\end{array}$ & $\begin{array}{l}-.281 * * \\
(.145)\end{array}$ & $\begin{array}{l}-.561 * * * \\
(.249)\end{array}$ & $\begin{array}{l}-.292 * \\
(.183)\end{array}$ \\
\hline HERIOTWT & $\begin{array}{l}-.444 * * * \\
(.191)\end{array}$ & $\begin{array}{l}-.456 * * * \\
(.191)\end{array}$ & $\begin{array}{l}-.534 * * * \\
(.217)\end{array}$ & $\begin{array}{l}-1.657 * * * \\
(.589)\end{array}$ & $\begin{array}{l}-.308 \\
(.211)\end{array}$ \\
\hline GLASGOW & $\begin{array}{l}-.374 * * * \\
(.125)\end{array}$ & $\begin{array}{l}-.364 * * * \\
(.125)\end{array}$ & $\begin{array}{l}-.354 * * * \\
(.136)\end{array}$ & $\begin{array}{l}-.466^{*} \\
(.255)\end{array}$ & $\begin{array}{l}-.427 * * * \\
(.153)\end{array}$ \\
\hline UNEMPLOY & $\begin{array}{l}.401 * * * \\
(.148)\end{array}$ & $\begin{array}{l}.427 * * * \\
(.148)\end{array}$ & $\begin{array}{l}.360 * * * \\
(.161)\end{array}$ & $\begin{array}{l}.339 \\
(.236)\end{array}$ & $\begin{array}{l}.519 * * * \\
(.204)\end{array}$ \\
\hline JOB1PRIV & $\begin{array}{l}.453 * * * \\
(.139)\end{array}$ & $\begin{array}{l}.453 * * * \\
(.139)\end{array}$ & $\begin{array}{l}.487 * * * \\
(.149)\end{array}$ & $\begin{array}{l}.471 * \\
(.250)\end{array}$ & $\begin{array}{l}.449 * * * \\
(.180)\end{array}$ \\
\hline AGE36OVR & $\begin{array}{l}-.109 \\
(.110)\end{array}$ & $\begin{array}{l}-.099 \\
(.110)\end{array}$ & $\begin{array}{l}-.145 \\
(.125)\end{array}$ & $\begin{array}{l}.350^{*} \\
(.205)\end{array}$ & $\begin{array}{l}-.372 * * * \\
(.138)\end{array}$ \\
\hline NOPROMOT & $\begin{array}{l}.069 \\
(.050)\end{array}$ & $\begin{array}{l}.067 \\
(.050)\end{array}$ & $\begin{array}{l}.059 \\
(.053)\end{array}$ & $\begin{array}{l}.450 * * * \\
(.132)\end{array}$ & $\begin{array}{l}.002 \\
(.056)\end{array}$ \\
\hline DISCREC & $\begin{array}{l}.008 \\
(.043)\end{array}$ & $\begin{array}{l}.002 \\
(.043)\end{array}$ & $\begin{array}{l}.007 \\
(.046)\end{array}$ & $\begin{array}{l}-.190 * * \\
(.094)\end{array}$ & $\begin{array}{l}.050 \\
(.051)\end{array}$ \\
\hline
\end{tabular}

\footnotetext{
${ }^{40}$ Derived from individual's own reports of the deserved pay - see variable list for definiation.

41 Follows the measure of subjective pay used in previous papers on job satisfaction such as Sloane and Williams (1996b) - see variable list for definition.
} 


\begin{tabular}{|c|c|c|c|c|c|}
\hline LECTRER & $\begin{array}{l}-.185 \\
(.122)\end{array}$ & $\begin{array}{l}-.184 \\
(.122)\end{array}$ & $\begin{array}{l}-.256^{* *} \\
(.133)\end{array}$ & $\begin{array}{l}.355^{*} \\
(.225)\end{array}$ & $\begin{array}{l}-.575 * * * \\
(.161)\end{array}$ \\
\hline SENREAD & $\begin{array}{l}-.192 \\
(.167)\end{array}$ & $\begin{array}{l}-.176 \\
(.167)\end{array}$ & $\begin{array}{l}-.223 \\
(.196)\end{array}$ & $\begin{array}{l}.335 \\
(.352)\end{array}$ & $\begin{array}{l}-.491 * * * \\
(.204)\end{array}$ \\
\hline PROFFOR & $\begin{array}{l}-.130 \\
(.194)\end{array}$ & $\begin{array}{l}-.104 \\
(.194)\end{array}$ & $\begin{array}{l}-.233 \\
(.235)\end{array}$ & $\begin{array}{l}.538 \\
(.526)\end{array}$ & $\begin{array}{l}-.452 * * \\
(.229)\end{array}$ \\
\hline SCIENCE & $\begin{array}{l}-.323 * * * \\
(.144)\end{array}$ & $\begin{array}{l}-.328 * * * \\
(.144)\end{array}$ & $\begin{array}{l}-.308 * \\
(.163)\end{array}$ & $\begin{array}{l}-.663 * \\
(.383)\end{array}$ & $\begin{array}{l}-.293^{*} \\
(.162)\end{array}$ \\
\hline SOCSCI & $\begin{array}{l}-.064 \\
(.152)\end{array}$ & $\begin{array}{l}-.077 \\
(.152)\end{array}$ & $\begin{array}{l}-.067 \\
(.171)\end{array}$ & $\begin{array}{l}-.790 * * \\
(.369)\end{array}$ & $\begin{array}{l}.108 \\
(.175)\end{array}$ \\
\hline MED & $\begin{array}{l}-.218 \\
(.149)\end{array}$ & $\begin{array}{l}-.199 \\
(.149)\end{array}$ & $\begin{array}{l}-.242 \\
(.170)\end{array}$ & $\begin{array}{l}-.723 * * \\
(.359)\end{array}$ & $\begin{array}{l}-.139 \\
(.176)\end{array}$ \\
\hline ARTS & $\begin{array}{l}-.032 \\
(.167)\end{array}$ & $\begin{array}{l}-.029 \\
(.167)\end{array}$ & $\begin{array}{l}-.060 \\
(.186)\end{array}$ & $\begin{array}{l}-.644 * \\
(.394)\end{array}$ & $\begin{array}{l}.003 \\
(.195)\end{array}$ \\
\hline CUT1 & $\begin{array}{l}-3.094 \\
(1.318)\end{array}$ & $\begin{array}{l}-3.069 \\
(1.318)\end{array}$ & $\begin{array}{l}-1.420 \\
(2.408)\end{array}$ & $\begin{array}{l}-6.850 \\
(1.733)\end{array}$ & $\begin{array}{l}-1.753 \\
(2.350)\end{array}$ \\
\hline CUT2 & $\begin{array}{l}-2.258 \\
(1.313)\end{array}$ & $\begin{array}{l}-2.248 \\
(1.313)\end{array}$ & $\begin{array}{l}-.681 \\
(2.412)\end{array}$ & $\begin{array}{l}-6.351 \\
(1.725)\end{array}$ & $\begin{array}{l}-.496 \\
(2.346)\end{array}$ \\
\hline CUT3 & $\begin{array}{l}-1.653 \\
(1.311)\end{array}$ & $\begin{array}{l}-1.654 \\
(1.311)\end{array}$ & $\begin{array}{l}-.015 \\
(2.413)\end{array}$ & $\begin{array}{l}-5.727 \\
(1.724)\end{array}$ & $\begin{array}{l}.142 \\
(2.339)\end{array}$ \\
\hline CUT4 & $\begin{array}{l}-1.173 \\
(1.310)\end{array}$ & $\begin{array}{l}-1.181 \\
(1.310)\end{array}$ & $\begin{array}{l}.489 \\
(2.413)\end{array}$ & $\begin{array}{l}-5.176 \\
(1.724)\end{array}$ & $\begin{array}{l}.624 \\
(2.334)\end{array}$ \\
\hline CUT5 & $\begin{array}{l}-.108 \\
(1.310)\end{array}$ & $\begin{array}{l}-.125 \\
(1.310)\end{array}$ & $\begin{array}{l}1.529 \\
(2.413)\end{array}$ & $\begin{array}{l}-4.012 \\
(1.724)\end{array}$ & $\begin{array}{l}1.714 \\
(2.332)\end{array}$ \\
\hline CUT6 & $\begin{array}{l}1.267 \\
(1.312)\end{array}$ & $\begin{array}{l}1.251 \\
(1.311)\end{array}$ & $\begin{array}{l}2.931 \\
(2.412)\end{array}$ & $\begin{array}{l}-2.359 \\
(1.727)\end{array}$ & $\begin{array}{l}3.075 \\
(2.327)\end{array}$ \\
\hline
\end{tabular}

* Statistically significant at the 0.10 level; **statistically significant at the 0.05 level; ***statistically significant at the 0.01 level.

\begin{tabular}{|l|lllll|}
\hline & All & All & All & Females & Males \\
\hline $\begin{array}{l}\text { Number of observations } \\
\text { Log of likelihood }\end{array}$ & 771 & 771 & 661 & 244 & 527 \\
function & -1090.679 & -1095.641 & -928.471 & -325.404 & -726.394 \\
\hline
\end{tabular}


Table 6: Ordered Probit regression, dependent variable: Overall job satisfaction

\begin{tabular}{|c|c|c|}
\hline & Females & Males \\
\hline LOGSAL & $\begin{array}{l}-.464 \\
(.309)\end{array}$ & $\begin{array}{l}-.316 \\
(.454)\end{array}$ \\
\hline SUBCOMP1 & $\begin{array}{l}-.189 \\
(.229)\end{array}$ & $\begin{array}{l}-.435^{* * *} \\
(.124)\end{array}$ \\
\hline ZIMPCOLL & $\begin{array}{l}.171 * * \\
(.079)\end{array}$ & $\begin{array}{l}.267 * * * \\
(.052)\end{array}$ \\
\hline ZIMPSPEC & $\begin{array}{l}.174 * * \\
(.082)\end{array}$ & $\begin{array}{l}.095^{*} \\
(.051)\end{array}$ \\
\hline ZIMPTEAC & $\begin{array}{l}.125^{*} \\
(.080)\end{array}$ & $\begin{array}{l}.118 * * \\
(.054)\end{array}$ \\
\hline ADVINTWK & $\begin{array}{l}.487 * * \\
(.245)\end{array}$ & $\begin{array}{l}.414 * * * \\
(.163)\end{array}$ \\
\hline ADVTRAVE & $\begin{array}{l}.445^{* * *} \\
(.157)\end{array}$ & $\begin{array}{l}.136 \\
(.106)\end{array}$ \\
\hline ADVWKENV & $\begin{array}{l}.456^{* * * *} \\
(.161)\end{array}$ & $\begin{array}{l}.327 * * * \\
(.104)\end{array}$ \\
\hline DISPROM & $\begin{array}{l}-.491 * * * \\
(.154)\end{array}$ & $\begin{array}{l}-.503 * * * \\
(.107)\end{array}$ \\
\hline DISREAL & $\begin{array}{l}-.464 * * * \\
(.186)\end{array}$ & $\begin{array}{l}-.659 * * * \\
(.158)\end{array}$ \\
\hline ABERDEEN & $\begin{array}{l}-.951 * * * \\
(.331)\end{array}$ & $\begin{array}{l}-.152 \\
(.173)\end{array}$ \\
\hline DUNDEE & $\begin{array}{l}-.567 * * * \\
(.256)\end{array}$ & $\begin{array}{l}-.279 \\
(.183)\end{array}$ \\
\hline HERIOTWT & $\begin{array}{l}-1.647 * * * \\
(.592)\end{array}$ & $\begin{array}{l}-.272 \\
(.213)\end{array}$ \\
\hline GLASGOW & $\begin{array}{l}-.470 * \\
(.266)\end{array}$ & $\begin{array}{l}-.410 * * * \\
(.155)\end{array}$ \\
\hline UNEMPLOY & $\begin{array}{l}.302 \\
(.238)\end{array}$ & $\begin{array}{l}.526 * * * \\
(.205)\end{array}$ \\
\hline JOB1PRIV & $\begin{array}{l}.472 * \\
(.250)\end{array}$ & $\begin{array}{l}.440 * * * \\
(.180)\end{array}$ \\
\hline AGE36OVR & $\begin{array}{l}.359 * \\
(.207)\end{array}$ & $\begin{array}{l}-.359 * * * \\
(.143)\end{array}$ \\
\hline NOPROMOT & $\begin{array}{l}.440 * * * \\
(.132)\end{array}$ & $\begin{array}{l}.009 \\
(.057)\end{array}$ \\
\hline DISCREC & $\begin{array}{l}-.181 * * \\
(.094)\end{array}$ & $\begin{array}{l}.058 \\
(.051)\end{array}$ \\
\hline LECTRER & $\begin{array}{l}1.082 \\
(4.649)\end{array}$ & $\begin{array}{l}-6.201 \\
(5.241)\end{array}$ \\
\hline SENREAD & $\begin{array}{l}-14.672 \\
(12.589)\end{array}$ & $\begin{array}{l}-3.955 \\
(5.400)\end{array}$ \\
\hline PROFFOR & $\begin{array}{l}21.482 \\
(28.180)\end{array}$ & $\begin{array}{l}-8.856 \\
(5.676)\end{array}$ \\
\hline SCIENCE & $\begin{array}{l}-.659 * \\
(.385)\end{array}$ & $\begin{array}{l}-.284^{*} \\
(.163)\end{array}$ \\
\hline SOCSCI & $\begin{array}{l}-.806 * * \\
(.372)\end{array}$ & $\begin{array}{l}.128 \\
(.176)\end{array}$ \\
\hline MED & $\begin{array}{l}-.718 * * \\
(.363)\end{array}$ & $\begin{array}{l}-.120 \\
(.177)\end{array}$ \\
\hline ARTS & $\begin{array}{l}-.649 * \\
(.395)\end{array}$ & $\begin{array}{l}.020 \\
(.196)\end{array}$ \\
\hline
\end{tabular}




\begin{tabular}{|l|ll|}
\hline SALLECT & -.072 & .568 \\
& $(.471)$ & $(.529)$ \\
SALSEN & 1.451 & .355 \\
& $(1.220)$ & $(.536)$ \\
SALPROF & -1.964 & .826 \\
& $(2.645)$ & $(.558)$ \\
\hline CUT1 & -7017 & -6.495 \\
& $(3.097)$ & $(4.446)$ \\
CUT2 & -6.521 & -5.250 \\
& $(3.085)$ & $(4.441)$ \\
CUT3 & -5.899 & -4.611 \\
& $(3.091)$ & $(4.441)$ \\
CUT4 & -5.343 & -4.126 \\
& $(3.088)$ & $(4.440)$ \\
CUT5 & -4.166 & -3.033 \\
& $(3.087)$ & $(4.440)$ \\
CUT6 & -2.510 & -1.668 \\
& $(3.082)$ & $(4.438)$ \\
\hline
\end{tabular}

*Statistically significant at the 0.10 level; **statistically significant at the 0.05 level; ***statistically significant at the 0.01 level.

\begin{tabular}{|l|ll|}
\hline & Females & Males \\
\hline Number of observations & 244 & 527 \\
Log of likelihood function & 121.66 & -725.103 \\
\hline
\end{tabular}


Table 7: Ordered Probit regression, dependent variable: Satisfaction with Promotion Prospects

\begin{tabular}{|c|c|c|c|}
\hline & All & Females & Males \\
\hline SEX & $\begin{array}{l}.271 * * * \\
(.094)\end{array}$ & $N A$ & $N A$ \\
\hline LOGSAL & $\begin{array}{l}.077 \\
(.145)\end{array}$ & $\begin{array}{l}-.150 \\
(.239)\end{array}$ & $\begin{array}{l}.180 \\
(.193)\end{array}$ \\
\hline SUBCOMP1 & $\begin{array}{l}-.451 * * * \\
(.112)\end{array}$ & $\begin{array}{l}-.605 * * * \\
(.250)\end{array}$ & $\begin{array}{l}-.450 * * * \\
(.126)\end{array}$ \\
\hline ZIMPENVR & $\begin{array}{l}.127 \\
(.048) * * *\end{array}$ & $\begin{array}{l}.249 * * \\
(.113)\end{array}$ & $\begin{array}{l}.148 * * * \\
(.056)\end{array}$ \\
\hline ZIMPCOLL & $\begin{array}{l}.105 * * \\
(.048)\end{array}$ & $\begin{array}{l}-.010 \\
(.010)\end{array}$ & $\begin{array}{l}.147 * * * \\
(.057)\end{array}$ \\
\hline ADVTRAVE & $\begin{array}{l}.163 * * \\
(.078)\end{array}$ & $\begin{array}{l}.107 \\
(.143)\end{array}$ & $\begin{array}{l}.167 * \\
(.095)\end{array}$ \\
\hline DISSAL & $\begin{array}{l}-.525 * * * \\
(.087)\end{array}$ & $\begin{array}{l}-.450 * * * \\
(.154)\end{array}$ & $\begin{array}{l}-.557 * * * \\
(.110)\end{array}$ \\
\hline PREJOB2 & $\begin{array}{l}-.624 * * * \\
(.209)\end{array}$ & $\begin{array}{l}-.597 * \\
(.368)\end{array}$ & $\begin{array}{l}-.623 * * * \\
(.263)\end{array}$ \\
\hline SHORTERM & $\begin{array}{l}-.472 * * * \\
(.121)\end{array}$ & $\begin{array}{l}-.585^{* * *} \\
(.230)\end{array}$ & $\begin{array}{l}-.426 * * * \\
(.147)\end{array}$ \\
\hline NUMPOSTS & $\begin{array}{l}.038 * * \\
(.020)\end{array}$ & $\begin{array}{l}-.027 \\
(.031)\end{array}$ & $\begin{array}{l}.092 * * * \\
(.028)\end{array}$ \\
\hline AGE36OVR & $\begin{array}{l}-.553 * * * \\
(.112)\end{array}$ & $\begin{array}{l}-.316^{*} \\
(.197)\end{array}$ & $\begin{array}{l}-.669 * * * \\
(.140)\end{array}$ \\
\hline LECTRER & $\begin{array}{l}-.002 \\
(.122)\end{array}$ & $\begin{array}{l}.140 \\
(.223)\end{array}$ & $\begin{array}{l}-.105 \\
(.154)\end{array}$ \\
\hline SENREAD & $\begin{array}{l}.361 * * * \\
(.160)\end{array}$ & $\begin{array}{l}.586^{*} \\
(.348)\end{array}$ & $\begin{array}{l}.297 * \\
(.186)\end{array}$ \\
\hline PROFFOR & $\begin{array}{l}1.316^{* * * *} \\
(.189)\end{array}$ & $\begin{array}{l}.248 \\
(.557)\end{array}$ & $\begin{array}{l}1.260 * * * \\
(.216)\end{array}$ \\
\hline CUT1 & $\begin{array}{l}-.596 \\
(1.452)\end{array}$ & $\begin{array}{l}-3.119 \\
(2.362)\end{array}$ & $\begin{array}{l}.222 \\
(1.929)\end{array}$ \\
\hline CUT2 & $\begin{array}{l}.051 \\
(1.452)\end{array}$ & $\begin{array}{l}-2.546 \\
(2.363)\end{array}$ & $\begin{array}{l}.927 \\
(1.929)\end{array}$ \\
\hline CUT3 & $\begin{array}{l}.489 \\
(1.452)\end{array}$ & $\begin{array}{l}-1.923 \\
(2.362)\end{array}$ & $\begin{array}{l}1.275 \\
(1.929)\end{array}$ \\
\hline CUT4 & $\begin{array}{l}1.263 \\
(1.452)\end{array}$ & $\begin{array}{l}-.998 \\
(2.359)\end{array}$ & $\begin{array}{l}2.017 \\
(1.930)\end{array}$ \\
\hline CUT5 & $\begin{array}{l}1.771 \\
(1.453)\end{array}$ & $\begin{array}{l}-.468 \\
(2.359)\end{array}$ & $\begin{array}{l}2.537 \\
(1.931)\end{array}$ \\
\hline CUT6 & $\begin{array}{l}2.159 \\
(1.453)\end{array}$ & $\begin{array}{l}-.043 \\
(2.361)\end{array}$ & $\begin{array}{l}2.931 \\
(1.931)\end{array}$ \\
\hline
\end{tabular}

*Statistically significant at the 0.10 level; **statistically significant at the 0.05 level; ***statistically significant at the 0.01 level.

\begin{tabular}{|l|lll|}
\hline & All & Females & Males \\
\hline $\begin{array}{l}\text { Number of observations } \\
\text { Log of likelihood }\end{array}$ & 768 & 241 & 527 \\
function & -1288.861 & -339.918 & -877.383 \\
\hline
\end{tabular}


Table 8: Ordered Probit regression, dependent variable: Satisfaction with Job Security

\begin{tabular}{|c|c|c|c|}
\hline & All & Females & Males \\
\hline SEX & $\begin{array}{l}.042 \\
(.102)\end{array}$ & NA & NA \\
\hline LOGSAL & $\begin{array}{l}.393^{* * *} \\
(.165)\end{array}$ & $\begin{array}{l}.611^{* *} \\
(.309)\end{array}$ & $\begin{array}{l}.584 * * * \\
(.226)\end{array}$ \\
\hline SUBCOMP1 & $\begin{array}{l}-.164 \\
(.111)\end{array}$ & $\begin{array}{l}-.595 * * * \\
(.261)\end{array}$ & $\begin{array}{l}-.027 \\
(.125)\end{array}$ \\
\hline ZIMPHR1 & $\begin{array}{l}.072 * \\
(.042)\end{array}$ & $\begin{array}{l}.049 \\
(.085)\end{array}$ & $\begin{array}{l}.103 * * \\
(.051)\end{array}$ \\
\hline DISREAL & $\begin{array}{l}-2.86 * * * \\
(.125)\end{array}$ & $\begin{array}{l}-.292 \\
(.204)\end{array}$ & $\begin{array}{l}-.216 \\
(.169)\end{array}$ \\
\hline PRECHANG & $\begin{array}{l}-.277 * * * \\
(.097)\end{array}$ & $\begin{array}{l}-.358 * * \\
(.188)\end{array}$ & $\begin{array}{l}-.244 * * \\
(.115)\end{array}$ \\
\hline SIZE1 & $\begin{array}{l}-.379 * * * \\
(.109)\end{array}$ & $\begin{array}{l}-.307 \\
(.201)\end{array}$ & $\begin{array}{l}-.368 * * * \\
(.135)\end{array}$ \\
\hline FULLTIME & $\begin{array}{l}-.180 \\
(.199)\end{array}$ & $\begin{array}{l}.699 * * \\
(.336)\end{array}$ & $\begin{array}{l}-1.25 * * * \\
(.304)\end{array}$ \\
\hline DISCREC & $\begin{array}{l}.135 * * * \\
(.045)\end{array}$ & $\begin{array}{l}.197 * * \\
(.102)\end{array}$ & $\begin{array}{l}.150 * * * \\
(.052)\end{array}$ \\
\hline ADVRESP & $\begin{array}{l}.504 * * * \\
(.082)\end{array}$ & $\begin{array}{l}.399 * * * \\
(.160)\end{array}$ & $\begin{array}{l}.457 \\
(.010)\end{array}$ \\
\hline SOCSCI & $\begin{array}{l}.385^{* * * *} \\
(.146)\end{array}$ & $\begin{array}{l}.269 \\
(.270)\end{array}$ & $\begin{array}{l}.416 * * * \\
(.178)\end{array}$ \\
\hline ENGINEER & $\begin{array}{l}.117 \\
(.169)\end{array}$ & $\begin{array}{l}-.853 * \\
(.514)\end{array}$ & $\begin{array}{l}.228 \\
(.189)\end{array}$ \\
\hline SCIENCE & $\begin{array}{l}-.085 \\
(.134)\end{array}$ & $\begin{array}{l}-.365 \\
(.285)\end{array}$ & $\begin{array}{l}.013 \\
(.154)\end{array}$ \\
\hline MED & $\begin{array}{l}-.041 \\
(.136)\end{array}$ & $\begin{array}{l}-.281 \\
(.235)\end{array}$ & $\begin{array}{l}-.066 \\
(.180)\end{array}$ \\
\hline ABERDEEN & $\begin{array}{l}-.264 * \\
(.149)\end{array}$ & $\begin{array}{l}-.375 \\
(.313)\end{array}$ & $\begin{array}{l}-.101 \\
(.175)\end{array}$ \\
\hline GLASGOW & $\begin{array}{l}-.311 * * * \\
(.122)\end{array}$ & $\begin{array}{l}-.778 * * * \\
(.247)\end{array}$ & $\begin{array}{l}-.007 \\
(.151)\end{array}$ \\
\hline HERIOTWT & $\begin{array}{l}-.336 * \\
(.188)\end{array}$ & $\begin{array}{l}.790 \\
(.841)\end{array}$ & $\begin{array}{l}-.250 \\
(.203)\end{array}$ \\
\hline DUNDEE & $\begin{array}{l}-.299 * * \\
(.137)\end{array}$ & $\begin{array}{l}-.60 * * * 1 \\
(.253)\end{array}$ & $\begin{array}{l}-.050 \\
(.181)\end{array}$ \\
\hline LECTRER & $\begin{array}{l}.267 * * \\
(.131)\end{array}$ & $\begin{array}{l}-.352 \\
(.270)\end{array}$ & $\begin{array}{l}.612 * * * \\
(.167)\end{array}$ \\
\hline SENREAD & $\begin{array}{l}.555^{* * * *} \\
(.162)\end{array}$ & $\begin{array}{l}-.290 \\
(.399)\end{array}$ & $\begin{array}{l}.825 * * * \\
(.191)\end{array}$ \\
\hline PROFFOR & $\begin{array}{l}.781 * * * \\
(.188)\end{array}$ & $\begin{array}{l}.257 \\
(.621)\end{array}$ & $\begin{array}{l}1.013 * * * \\
(.216)\end{array}$ \\
\hline SHORTERM & $\begin{array}{l}-1.315^{* * * *} \\
(.129)\end{array}$ & $\begin{array}{l}-1.731 * * * \\
(.262)\end{array}$ & $\begin{array}{l}-1.307 * * * \\
(.159)\end{array}$ \\
\hline NUMPOSTS & $\begin{array}{l}-.045^{* *} \\
(.022)\end{array}$ & $\begin{array}{l}-.086 * * \\
(.039)\end{array}$ & $\begin{array}{l}-.005 \\
(.027)\end{array}$ \\
\hline
\end{tabular}




\begin{tabular}{|l|lll|}
\hline CUT1 & 1.918 & 3.574 & 3.331 \\
& $(1.570)$ & $(3.012)$ & $(2.114)$ \\
CUT2 & 2.416 & 4.021 & 3.971 \\
& $(1.571)$ & $(3.013)$ & $(2.116)$ \\
CUT3 & 2.694 & 4.375 & 4.228 \\
& $(1.572)$ & $(3.016)$ & $(2.117)$ \\
CUT4 & 3.242 & 4.984 & 4.803 \\
& $(1.574)$ & $(3.021)$ & $(2.120)$ \\
CUT5 & 3.914 & 5.883 & 5.427 \\
& $(1.575)$ & $(3.028)$ & $(2.121)$ \\
CUT6 & 4.791 & 6.649 & 6.357 \\
& $(1.575)$ & $(3.029)$ & $(2.122)$ \\
\hline
\end{tabular}

* Statistically significant at the 0.10 level; **statistically significant at the 0.05 level; ***statistically significant at the 0.01 level.

\begin{tabular}{|l|lll|}
\hline & All & Females & Males \\
\hline Number of observations & 761 & 525 & 237 \\
Log of likelihood function & -1152.4275 & 342.42 & -337.595 \\
\hline
\end{tabular}


Table 9: Ordered Probit regression, dependent variable: Satisfaction with salary

\begin{tabular}{|c|c|c|c|}
\hline & All & Females & Males \\
\hline SEX & $\begin{array}{l}-.153 \\
(.096)\end{array}$ & $\mathrm{NA}$ & $\mathrm{NA}$ \\
\hline LOGSAL & $\begin{array}{l}.269 * * \\
(.128)\end{array}$ & $\begin{array}{l}.038 \\
(.212)\end{array}$ & $\begin{array}{l}.572 * * * \\
(.173)\end{array}$ \\
\hline SUBCOMP1 & $\begin{array}{l}-1.364 * * * \\
(.120)\end{array}$ & $\begin{array}{l}-1.448 * * * \\
(.263)\end{array}$ & $\begin{array}{l}-1.384 * * * \\
(.139)\end{array}$ \\
\hline ZIMPTEAC & $\begin{array}{l}.074 * \\
(.043)\end{array}$ & $\begin{array}{l}.003 \\
(.077)\end{array}$ & $\begin{array}{l}.115^{* *} \\
(.054)\end{array}$ \\
\hline ZIMPCOLL & $\begin{array}{l}.149 * * * \\
(.042)\end{array}$ & $\begin{array}{l}.084 \\
(.074)\end{array}$ & $\begin{array}{l}.168 * * * \\
(.053)\end{array}$ \\
\hline DISPROM & $\begin{array}{l}-.523 * * * \\
(.085)\end{array}$ & $\begin{array}{l}-.466^{* * *} \\
(.152)\end{array}$ & $\begin{array}{l}-.596 * * * \\
(.105)\end{array}$ \\
\hline AGE36OVR & $\begin{array}{l}.020 \\
(.109)\end{array}$ & $\begin{array}{l}.511 * * * \\
(.197)\end{array}$ & $\begin{array}{l}-.321 * * * \\
(.136)\end{array}$ \\
\hline PUBPAPS & $\begin{array}{l}.002 * \\
(.001)\end{array}$ & $\begin{array}{l}-.015 * * \\
(.007)\end{array}$ & $\begin{array}{l}.003^{* *} \\
(.001)\end{array}$ \\
\hline SCOTDEG1 & $\begin{array}{l}.168 * * \\
(.081)\end{array}$ & $\begin{array}{l}.304^{* *} \\
(.149)\end{array}$ & $\begin{array}{l}.129 \\
(.099)\end{array}$ \\
\hline JOB1SCOT & $\begin{array}{l}-.156^{*} \\
(.091)\end{array}$ & $\begin{array}{l}.020 \\
(.161)\end{array}$ & $\begin{array}{l}-.265^{* * *} \\
(.114)\end{array}$ \\
\hline TEACHER & $\begin{array}{l}-1.098 * * \\
(.540)\end{array}$ & $\begin{array}{l}-1.093 \\
(.983)\end{array}$ & $\begin{array}{l}-.148 * * \\
(.669)\end{array}$ \\
\hline RECCHANG & $\begin{array}{l}-.345^{* *} \\
(.164)\end{array}$ & $\begin{array}{l}-.066 \\
(.221)\end{array}$ & $\begin{array}{l}-1.062 * * * \\
(.270)\end{array}$ \\
\hline LECTRER & $\begin{array}{l}-.095 \\
(.116)\end{array}$ & $\begin{array}{l}.234 \\
(.212)\end{array}$ & $\begin{array}{l}-.368 * * * \\
(.151)\end{array}$ \\
\hline SENREAD & $\begin{array}{l}-.097 \\
(.159)\end{array}$ & $\begin{array}{l}.658 \\
(.348)\end{array}$ & $\begin{array}{l}-.392 * * \\
(.189)\end{array}$ \\
\hline PROFFOR & $\begin{array}{l}-.119 \\
(.185)\end{array}$ & $\begin{array}{l}-.244 \\
(.4950\end{array}$ & $\begin{array}{l}-.428 * * \\
(.214)\end{array}$ \\
\hline SCIENCE & $\begin{array}{l}-.287 * * \\
(.137)\end{array}$ & $\begin{array}{l}-.055 \\
(.364)\end{array}$ & $\begin{array}{l}-.352 * * * \\
(.149)\end{array}$ \\
\hline SOCSCI & $\begin{array}{l}-.149 \\
(.149)\end{array}$ & $\begin{array}{l}-.109 \\
(.360)\end{array}$ & $\begin{array}{l}-.258 \\
(.171)\end{array}$ \\
\hline MED & $\begin{array}{l}-.269 * * \\
(.1400\end{array}$ & $\begin{array}{l}-.167 \\
(.338)\end{array}$ & $\begin{array}{l}-.281 * \\
(.162)\end{array}$ \\
\hline ARTS & $\begin{array}{l}-.068 \\
(.149) \\
\end{array}$ & $\begin{array}{l}-.251 \\
(.365) \\
\end{array}$ & $\begin{array}{l}-.087 \\
(.166) \\
\end{array}$ \\
\hline CUT1 & $\begin{array}{l}.662 \\
(1.244)\end{array}$ & $\begin{array}{l}-1.428 \\
(2.018)\end{array}$ & $\begin{array}{l}3.355 \\
(1.698)\end{array}$ \\
\hline CUT2 & $\begin{array}{l}1.369 \\
(1.243)\end{array}$ & $\begin{array}{l}-.707 \\
(2.011)\end{array}$ & $\begin{array}{l}4.095 \\
(1.699)\end{array}$ \\
\hline CUT3 & $\begin{array}{l}1.892 \\
(1.243)\end{array}$ & $\begin{array}{l}-.065 \\
(2.012)\end{array}$ & $\begin{array}{l}4.591 \\
(1.700)\end{array}$ \\
\hline CUT4 & $\begin{array}{l}2.695 \\
(1.245)\end{array}$ & $\begin{array}{l}1.096 \\
(2.015)\end{array}$ & $\begin{array}{l}5.264 \\
(1.702)\end{array}$ \\
\hline CUT5 & $\begin{array}{l}3.311 \\
(1.247)\end{array}$ & $\begin{array}{l}1.645 \\
(2.017)\end{array}$ & $\begin{array}{l}5.968 \\
(1.706)\end{array}$ \\
\hline CUT6 & $\begin{array}{l}3.805 \\
(1.249)\end{array}$ & $\begin{array}{l}2.296 \\
(2.022)\end{array}$ & $\begin{array}{l}6.428 \\
(1.709)\end{array}$ \\
\hline
\end{tabular}

* Statistically significant at the 0.10 level; **statistically significant at the 0.05 level; ***statistically significant at the 0.01 level.

\begin{tabular}{|l|lll|}
\hline & All & Females & Males \\
\hline Number of observations & 750 & 235 & 515 \\
Log of likelihood & -1253.2335 & -363.855 & -850.463 \\
function & & & \\
\hline
\end{tabular}




\section{REFERENCES}

Akerlof, G. A., Rose, A. K. and Yellen, J. L. (1988), 'Job switching and job satisfaction in the US Labor Market' Brookings Papers on Economic Activity, Vol. 2, pp.495-582.

Bartel, A. P (1981), 'Race Differences in Job Satisfaction: A Reappraisal', Journal of Human Resources, Vol. 16, pp.295-303.

Borjas, G. J. (1979), 'Job Satisfaction, Wages and Unions,' Journal of Human Resources, Vol. XIV, No. 1, pp.21-40.

Clark, A. E. (1995), 'Is Utility Relative? Evidence from Household Data', DELTA.

Clark, A. E. (1996), 'Job Satisfaction in Britain' British Journal of Industrial Relations, Vol. 34, pp 189-218.

Clark, A. E. (1997), 'Job Satisfaction and Gender: Why are women so Happy at Work?' Labour Economics, Vo. 4, No. 4, December pp 341-372.

Clark, A. E. and Oswald, A. J. (1996), 'Satisfaction, and Comparison Income', Journal of Public Economics, Vol. 61, No. 3, September pp 359-382.

Clegg, C. W. (1983), 'Psychology of Employee Lateness, Absence and Turnover: A Methodological Critique and an Empirical Study', Journal of Applied Psychology, Vol. 68, pp.88-101.

Court, S. (1994), Long Hours, Little Thanks, Association of University Teachers.

Dolton, P. J. and Makepeace, G. (1987), 'Marital Status, Child-Rearing and Earnings Differentials in the Graduate Labour Market', Economic Journal, Vol. 97, pp.897922.

Freeman, R. B. (1978), 'Job Satisfaction as an Economic Variable', American Economic Review, May, Vol. 68, pp.135-141.

Greenhalgh, C. (1980), Male-Female Differentials in Great Britain: Is Marriage an Equal Opportunity?, Economic Journal, Vol. 90, pp.751-775.

Hamermesh, D. S. (1977), 'Economic Aspects of Job Satisfaction, in Ashenfelter, O.E and Oates, W.E, editors, Essays in Labor Market Analysis, John Wiley, New York, pp.53-72.

Idson, T.,L. (1990), 'Establishment Size, Job Satisfaction and Structure of Work' Applied Economics, Vol. 11, No. 4, pp.606-28.

Joshi, H. E. and Newell, M. (1987), 'Pay Differences between Men and Women: Longitudinal Evidence from the 1946 Birth Cohort' Centre for Economic Policy Research, Discussion paper 156. 
Lazear, E. P. and Rosen, S. (1990), 'Male-Female Differentials in Job Ladders', Journal of Labor Economics, Vol. 8, S106 - S123.

Mangione, T. W. and Quinn, R. P. (1975), 'Job Satisfaction, Counterproductive Behaviour and Drug use at work' Journal of Applied Psychology, Vol. 60, pp.114-16.

McEvoy, G. M and Cascio, W. F. (1985), 'Strategies for Reducing Employee Turnover; A Meta-Analysis' Journal of Applied Psychology, Vol.70, pp.342-53.

McNabb, R. and Wass, V. (1995), Gender Differences in British Academic Salaries and Promotion Probabilities. Unpublished.

Miller, P. W. (1987), 'The Wage Effect of The Occupational Segregation of Women in Britain', The Economic Journal, Vol. 97, pp.885-896.

Miller, P. (1990), 'Trade Unions and Job satisfaction', Australian Economic Papers, Vol. 29, pp.226-248.

National Committee of Inquiry into Higher Education (1997), Higher Education in the Learning Society, Report of the National Committee, Main Report, HMSO, July.

Riach, P. A. and Rich, J. (1987), 'Testing for Sexual Discrimination in the Labour Market', Australian Economic Papers, Vol. 26, pp.165-178.

Sloane, P. J and Williams, H. (1996a), 'Are "Overpaid" Workers really unhappy? A Test of the Theory of Cognitive Dissonance' Labour, Vol. 10, No. 1, pp.3-15.

Sloane, P. J and Williams, H. (1996b), 'Job Satisfaction, Comparison Income and Gender' Unpublished.

Watson, R., Storey, D., Wynarczyk, P., Keasey, K. and Short, H. (1996), 'The Relationship Between Job Satisfaction and Managerial Remuneration in Small and Medium-Sized Categories: An Empirical Test of Comparison Income and Equity Theory Hypotheses, Applied Economics, Vol. 28, pp.567-576.

Weiler, W. (1990), 'Integrating Rank Differences into a Model of Male-Female Salary Discrimination', Quarterly Review of Economics and Business, Vol. 30, No. 1, pp.315.

Wright, R. E. and Ermisch, J. F. (1991), 'Gender Discrimination in the British Labour Market: A Re-Assessment', Economic Journal, Vol. 101, No. 406, pp.508-521.

Zabalza, A. and Arrufat, J. L. (1985), 'The extent of sex discrimination in Great Britain', in Women and Equal Pay: The effects of legislation on female wages and employment in Britain, (A. Zabalza and Z. Tzannatos, eds), pp.70-96, Cambridge University Press. 